\title{
Reading Under Digital Constraints
}

\section{Media and Usage}

Ce que le numérique fait à la lecture. Distinguer les supports, questionner les usages

Efectos de la digitalización en la lectura. Distinguir los soportes, cuestionar los usos

\section{Cécile Rabot}

Translator. Katharine Throssell

\section{(2) OpenEdition}

1 Journals

\section{Electronic version}

URL: http://journals.openedition.org/bssg/476

DOI: $10.4000 /$ bssg.476

ISSN: 2490-9424

\section{Publisher}

Presses universitaires de Vincennes

\section{Electronic reference}

Cécile Rabot, "Reading Under Digital Constraints", Biens Symboliques / Symbolic Goods [Online], 7 | 2020, Online since 20 November 2020, connection on 04 March 2021. URL: http:// journals.openedition.org/bssg/476 ; DOl: https://doi.org/10.4000/bssg.476 
BIENS

SYMBOLIQUES

SYMBOLIC

GOODS

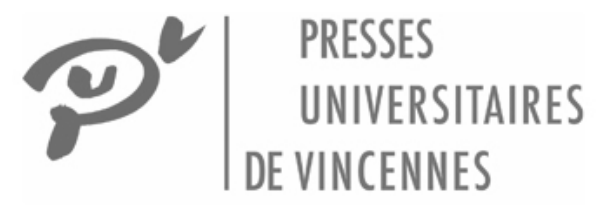

SYMBOLIQUES

Revue de sciences sociales sur les arts, la culture et les idées

is leurs racines et du soleil dans nt des cassolettes d'encens et fumer fums à la fois. Tout rit, chainle et loucement ivre. Le printemops est uir e; le soleil aide à faire patienter des êtres qui n'en demanderit pas das rui, ayant l'azur du ciel, disenf: :e'es absorbés dans le prodige, apuisant dar la nature l'indifférence du bien et lateurs du cosmos radieusement dist mil ne comnre ${ }^{\circ} 7 / 2020$ as au'on_s'ecom

\section{Lire en numérique} Digital Readings 
Ce que le numérique fait à la lecture

Reading Under Digital Constraints

Distinguer les supports, Media and Usage questionner les usages

Cécile Rabot

traduction | translation

Katharine Throssel

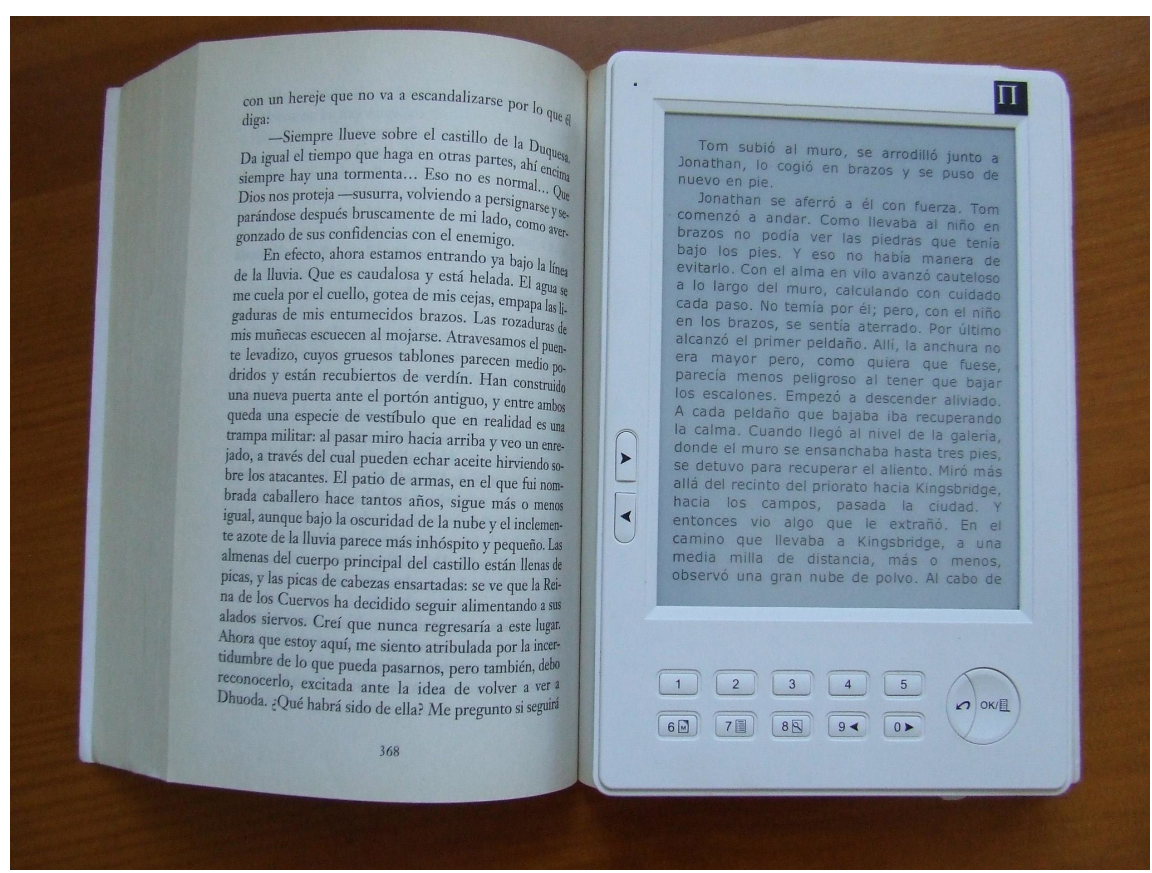

Livre et liseuse / Book and e-book

Source : Flickr, photo de Josemaria / Flickr, picture by Josemaria 
Le numérique a engendré de profonds bouleversements des industries culturelles et de certaines pratiques culturelles, notamment audiovisuelles. Le cinéma et la musique ont dans leur ensemble, de leur production à leur distribution et à leur consommation, été marqués par ce que d'aucuns qualifient de « numérimorphose » (Granjon \& Combes 2007) : les plateformes jouent aujourd'hui un rôle incontournable et le streaming révolutionne les modes d'accès au son et à l'image, musique, radio, films, séries ou vidéos. Qu'en est-il de l'accès aux textes et des pratiques de lecture ? Le numérique a-t-il produit dans ce domaine une semblable « révolution » (comme le suggère par exemple Rieffel 2014)?

Le numérique a eu, sur l'industrie du livre comme sur l'ensemble des industries culturelles et informationnelles, des effets multiples. Bertrand Legendre a tenté, dans un ouvrage récent, de les inventorier en parcourant la chaîne du livre dans les différents secteurs éditoriaux (Legendre 2019). De la production à la fabrication, de la distribution à la prescription, il n'est guère de point de cette chaîne qui n'ait été, si ce n'est profondément modifié, du moins touché par le développement des outils numériques. Logiciels de traitement de texte, de correction ou de composition, plateformes d'écriture numérique, bases de données iconographiques et autre documentation disponible sur le web, mais aussi courriels et documents collaboratifs ont largement modifié les manières de travailler des auteur.rice.s comme des éditeur.rice.s. Plateformes de vente en ligne, réseaux sociaux du livre (de Babelio à Booktube et Bookstagram), blogs de libraires ou de lecteur.rice.s ordinaires, bibliothèques numérisées et catalogues en ligne, ont transformé la diffusion et les manières de s'informer sur les livres (voir Leveratto \& Leontsini 2008 ; Wiart 2017) et de se les procurer.
Digital technology has had a profound impact on the cultural industries and certain cultural practices, specifically in the audiovisual sector. As a whole, film and music, from production to distribution to consumption, have been affected by what some call a "digimorphosis" [numérimorphose] (Granjon \& Combes 2007). Today, online platforms play an undeniable role, and streaming has revolutionized access to sound and images, music, radio, film, series, and videos. Has digital technology produced a similar "revolution" in texts and reading practices (as Rieffel 2014, for instance, suggests)?

Digital technology has had multiple effects on the book industry, as with other sectors of the cultural and information industries. In a recent work, Bertrand Legendre attempts to classify these effects by following the book production chain in various editorial sectors (Legendre 2019). From production to manufacture, distribution to promotion, no stage of this process has been left untouched by the development of digital tools - and some have even been profoundly transformed. Word processing, correction, and composition software, digital writing platforms, image databases, and other documentation available online, but also e-mail and collaborative documents have greatly transformed the ways in which authors and editors work. Online sales platforms, book social media sites (from Goodreads to Booktube and Bookstagram), blogs by booksellers or ordinary readers, digital libraries and online catalogues have all transformed distribution and ways of getting information about books (see Leveratto \& Leontsini 2008; Wiart 2017) and of acquiring them. 
Qu'en est-il en revanche de la lecture proprement dite ? Le terme lecture recouvre lui-même des acceptions différentes. On peut se demander ce que change le passage à l'écran pour la "lecture " prise au sens large de " déchiffrage d'écrit en vue de produire une signification » (en excluant donc une acception encore plus large qui renverrait au décodage de toute forme de signes). La lecture informative intentionnelle, dans laquelle le lecteur ou la lectrice cherchent une information, a de fait été profondément modifiée par internet, les moteurs de recherche, les dictionnaires en ligne, les encyclopédies collaboratives comme Wikipedia ou encore les forums (voir Jouët \& Rieffel 2013 ; Barbe, Merzeau, Schafer 2015). Que change le numérique à la lecture comme pratique culturelle ou de loisir, c'est-à-dire comme pratique qu'on pourrait dire plus désintéressée, au sens où elle ne vise pas un but spécifique, même si elle remplit souvent de fait plusieurs fonctions (voir Mauger \& Poliak 1998) ? Cette lecture faite pour le plaisir de lire, de se procurer des émotions, d'apprendre sans but précis, de se cultiver, de réfléchir, celle qu'Armando Petrucci désigne par la formule tautologique « lire pour lire » (Petrucci 1990), a-t-elle été modifiée par l'arrivée du numérique ? Qu'elle porte sur des objets littéraires (dans une acception large du terme, incluant les différents genres sans distinction de légitimité) ou des essais, elle était précédemment associée au livre (et continue en partie de passer par lui). Si l'on peut parler de « métamorphose du lecteur" (Assouline 2012), quel rôle y tient le numérique?

La Bibliothèque nationale de France organisait le 4 mai 2017 dans le cadre des $\underline{\text { Ateliers du livre }}^{1}$ une journée d'étude intitulée

1. Les Ateliers du livre forment un cycle de réflexion sur le livre, les institutions et les pratiques qui lui sont liées. Ils sont organisés par la Bibliothèque nationale de France au rythme de deux journées par an. La journée de printemps est coorganisée par le master métiers du livre et de l'édition de l'Université Paris Nanterre. Elle porte sur des enjeux contemporains, ici la lecture numérique.
But what about reading per se? The term "reading" has various meanings. We can question how the transition to screens has impacted on "reading" in the wider sense, defined as "deciphering the written in view of procuring sense" (thus excluding an even larger meaning which would refer to decoding all kinds of signs). Intentional informative reading, in which the reader looks for information, has indeed been profoundly transformed by the internet, search engines, online dictionaries, and collaborative encyclopaedias such as Wikipedia, or even forums (see Jouët \& Rieffel 2013; Barbe, Merzeau, Schafer 2015). How does digital technology impact on reading as a cultural practice or pastime, i.e. as a practice that could be qualified as disinterested in the sense that it does not have a specific aim, even though it often in fact fulfils several functions (see Mauger \& Poliak 1998)? This kind of reading for pleasure is what Armando Petrucci defines by the tautology "reading for reading's sake" (Petrucci 1990). It involves experiencing emotions, learning without a specific aim in mind, culturally educating oneself, and thinking. Has this been transformed by the arrival of digital technology? Whether the term is used to refer to literary objects (in the wider sense of the term, including various genres that have no distinction of legitimacy) or essays, it is traditionally associated with books (and still in part exists through them). If a "metamorphosis of the reader" indeed exists (Assouline 2012), how does digital technology play into it?

On 4 May 2017, the Bibliothèque nationale de France organized a seminar as part of the Ateliers du livre series ${ }^{1}$ called "Reading Digitally: Realities and Perspectives," which this dossier builds

1. The Ateliers du livre are a series of workshops reflecting on books, along with the institutions and practices that are linked to them. They are organized by the Bibliothèque nationale de France and take place over two days annually. Each year, the spring edition is co-organized by the book trade 
«Lire en numérique : réalités et perspectives », dont ce dossier est le prolongement. Au principe de cette journée se trouvait le constat d'une abondance de textes sur « la révolution numérique » dans le paysage médiatique et éditorial - abondance sans doute significative de l'intérêt des éditeur.rice-s eux/elles-mêmes pour une question qui met en jeu, si ce n'est leur existence, du moins la nature de leur activité et peut-être leur identité. Très nombreux, ces textes étaient aussi dans leur grande majorité des essais, théoriques et prospectifs - en particulier ceux de l'orée du $x \mathrm{Il}^{\mathrm{e}}$ siècle. Peu empiriques, ces essais considèrent ce que le numérique peut faire au lecteur. Ils laissent par ailleurs le plus souvent transparaître assez nettement le positionnement de l'auteur.rice (sans que celui/ celle-ci soit interrogé $\cdot e$ dans une quelconque démarche réflexive) soit du côté des espoirs suscités par ces nouvelles technologies, soit du côté des menaces qu'elles font planer sur les industries culturelles, voire sur la culture. Nous reviendrons dans un instant sur ces textes et leurs présupposés.

D'autres publications, plus empiriques, se limitent à faire du numérique un contexte en analysant par exemple « Les pratiques culturelles des Français à l'ère numérique " (Donnat 2008) ou «Lectures et lecteurs à l'heure d'Internet " (Evans 2011)2. D'autres, comme ceux précédemment cités, se concentrent sur l'amont de la chaîne du livre, de la production à la prescription, avec de possibles effets sur le/la lecteur.rice, ses modes d'information et de sélection, des pratiques d'approvisionnement et de partage, mais sans explorer la réalité de ces effets ou en tout cas sans inclure les pratiques de lecture sur support numérique. D'autres (nous y reviendrons) apportent quelques éléments quantitatifs sur ces pratiques, dans une optique de mesure mais sans permettre de les comprendre, c'est-à-dire de saisir leurs raisons d'être telles

2. Nous soulignons. upon. The starting point of this seminar was an acknowledgment of the abundance of texts on the "digital revolution" in the media and publishing worlds. This abundance is doubtless a mark of the publishers' own stakes in an issue that puts the nature of their work and perhaps their identity, if not their very existence, into play. These numerous texts were mainly theoretical and prospective essays-especially those from the dawn of the twenty-first century. These primarily unempirical texts examined what the digital sphere could do to readers. Furthermore, the authors' positions were often quite clear (although the authors were not particularly engaged in a reflexive approach), either emphasizing the hope kindled by these new technologies, or underlining the threat that they seemed to represent for cultural industries or even culture itself. We shall return to these texts and their assumptions below.

Other more empirical publications were limited to considering digital technology as a context, for instance, analysing "French cultural practices in the digital age"(Donnat 2008) or "Reading and readers in the Internet age" (Evans 2011). Others, like those cited above, focused higher up in the book chain, from production to the act of recommendation and the possible effects on readers, their information and selection modes and their acquisition and sharing practices, without exploring the reality of these effects or at least including reading practices on digital mediums. Others (which we shall come back to) contributed quantitative elements to these practices in view of measuring them, but without allowing for a full understanding, i.e. understanding their relevance for

and the master's programme in book-related professions at Paris Nanterre University. It deals with contemporary issues, in this case digital reading 
qu'elles apparaissent à la conscience des enquêté·e·s et encore moins les logiques qui pourraient les pousser à leur insu. L'ambition de la journée était, a contrario, d'interroger les pratiques effectives de lecture numérique, en rassemblant des éléments de savoir produits dans des cadres disciplinaires variables (de la sociologie aux neurosciences en passant par l'histoire et les sciences de l'information et de la communication). C'est aussi la perspective

de ce dossier

\section{Entre enchantement et déploration}

La lecture numérique a en effet donné lieu, surtout dans la première décennie du $x \mathrm{XI}^{\mathrm{e}}$ siècle, à des discours multiples, entre enchantement et déploration, qui rappellent, mutatis mutandis, les écueils (du misérabilisme et du populisme) pointés par Claude Grignon et Jean-Claude Passeron à propos de l'étude des cultures populaires (Grignon \& Passeron 1989). Tantôt elle est présentée comme une révolution, équivalente à l'invention de l'imprimerie ou au passage du volumen au codex, qui ouvrirait des possibles insoupçonnés en modifiant en profondeur le rapport à la connaissance et à la création ; tantôt (et peut-être davantage encore) elle cristallise les craintes conservatrices en faisant envisager la mort du livre et, avec lui, de la culture véritable, au profit du divertissement : elle incarne alors la baisse du niveau d'exigence, les dangers du relativisme ou la dispersion de l'attention.

Les discours optimistes mettent en avant les possibles ouverts par la « révolution numérique ». L'offre de lecture devient quasi infinie. L'information est accessible à distance et sans délai. Le numérique est aussi associé aux fonctionnalités spécifiques qu'il offre généralement (quoique pas systématiquement). Ces fonctionnalités facilitent à la fois les interactions (commentaire, partage), l'accès à l'information et la mise en relation (via des outils de recherche et le the respondents, or the logic that could unwittingly drive them. In contrast, the aim of the seminar was to question the effective practices of digital reading, bringing together elements of knowledge produced in variable disciplinary frameworks (from sociology to neuroscience through history and information and communication sciences), which is also the perspective for the present dossier.

\section{Between Delight and Lamentation}

Digital reading has given rise, during the first decade of the twentyfirst century especially, to varied discourse ranging from delight to lamentation. This mutatis mutandis recalls the two pitfalls of 'miserabilism and populism' as highlighted by Claude Grignon and Jean-Claude Passeron in the study of popular culture (Grignon \& Passeron 1989). Some voices present digital reading as a revolution equivalent to the invention of the printing press or the shift from volumen to codex, which might open up unsuspected possibilities by deeply modifying our relationship to knowledge and creation. For others (perhaps a majority), it crystallizes conservative fears by foreshadowing the death of books - and, with it, of real cultureto the profit of entertainment: it thus represents a decrease in quality requirements, the dangers of relativism or the dispersion of attention.

Optimistic voices showcase the possibilities opened up by the "digital revolution." The literature on offer has become practically infinite. Information is accessible remotely and instantly. Digital technology is also linked to the specific functions that it generally (though not systematically) offers. These functions facilitate interaction (comments, sharing, etc.) as well as access to information and connections (via search tools and hyperlinks). Faced with some 
système des liens hypertextes). Arrêté·e par une difficulté (lexicale ou référentielle par exemple), le/la lecteur.rice peut, grâce aux dictionnaires intégrés, la lever de manière beaucoup plus immédiate qu'il/elle ne pouvait le faire auparavant via les dictionnaires, encyclopédies ou autres ouvrages disponibles. Désireux.se de faire part de son opinion ou de faire connaître le texte, il/elle peut le partager ou le commenter instantanément ou publiquement, bien au-delà du cercle de proches qui, antérieurement, constituait le plus souvent le marché sur lequel il/elle pouvait échanger sur ses lectures. II/elle peut aussi échanger directement et rapidement avec l'auteur.rice du texte (avec peut-être des effets sur le texte lui-même ou sa suite) (voir Petitjean \& Houdart-Merot 2015), beaucoup plus facilement que ne pouvait le faire le lecteur ou la lectrice adressant un courrier à l'éditeur.rice ou à l'auteur-rice (voir Lyon-Caen 2006). Ces facilités de navigation intertextuelle et ces sociabilités littéraires élargies participent à la fascination suscitée par le numérique, qui est vu comme une formidable ouverture de possibles (au moins théoriques)

Plus nombreux ou plus visibles sont les discours qui pointent les dangers de cette mutation des outils et des pratiques. Dominique Boullier écrit ainsi : «Le Web 2.0 n'est pas une mode, c'est tout notre rapport aux réseaux numériques qui a changé et, dans le même tourbillon, la lecture au long cours a été emportée " (Boullier 2011 : 41). L'image du tourbillon mobilisée ici n'est pas sans rappeler celle des « torrents de papier » qui avait été utilisée pour décrire, au XIX ${ }^{\mathrm{e}}$ siècle, la diffusion massive d'une production imprimée industrialisée réputée dangereuse, au moins pour les lecteurs les moins aguerris et les lectrices (Artiaga 2007). À l'instar de l'industrialisation de l'édition, le numérique est accusé de mettre en péril la lecture et/ou les lecteur.rice-s en les emportant et en les détournant. Les intitulés de nombre de ces textes les inscrivent dans un registre polémique ou apologétique : « Les livres ont difficulties (lexical or referential, for instance), thanks to integrated dictionaries, readers are able to find solutions much faster than they could before using dictionaries, encyclopaedia or other available works. If they wish to share their opinion or the text itself, they can share or comment upon it instantly or publicly, well beyond their close circle of family and friends, which was previously the only audience with whom they could discuss the books they read. They can also exchange with the texts' authors quickly and directly (with potential repercussions on the text itself or its followup) (see Petitjean \& Houdart-Merot 2015). It is much easier to do so now than previously, when readers would write a letter to the publisher or the author (see Lyon-Caen 2006). Such intertextual browsing and extended literary sociability facilities contribute to the fascination triggered by the use of digital technology, which is seen as a tremendous opening up of possibilities (at least theoretically speaking).

Discourse that points towards the dangers of this shift in tools and practices is more common, or more visible. Dominique Boullier writes: "Web 2.0 is not a fashion, our relationship to digital networks has changed, and in-depth reading has been sucked into the same whirlpool for the long term" (Boullier 2011: 41). This image of a whirlpool reminds us of the "torrents of paper" conjured up in the nineteenth century to describe the mass distribution of industrial-scale printed production, deemed dangerous for female readers or less experienced male readers (Artiaga 2007). Like the industrialization of publishing, digital technology is accused of putting readers in danger by carrying them away or distracting them. The titles in French of many of these texts indicate the register of controversy and praise: "Books Need Us" (Steiner 2008); "Don't Hope to Get Rid of Your Books" (Carriere \& Eco 2009); "The Case 
besoin de nous " (Steiner 2008); N'espérez pas vous débarrasser des livres (Carrière \& Eco 2009) ; Apologie du livre (Darnton 2011) ; Contre le colonialisme numérique : manifeste pour continuer à lire

(Casati 2013) ; Les Ravages des écrans (Spitzer 2019).

Ces discours sur « le numérique » ont en commun de regrouper derrière cet adjectif substantivé (Moatti 2012) toutes les formes de numérique sans aucune forme de distinction, au prix de généralisations hâtives, voire abusives. Ils ne se comprennent qu'au regard du livre papier et de la valeur qui lui est accordée. Le livre papier devient le symbole de la culture - une culture humaniste, littéraire, mais souvent mal définie - et il suscite des attachements d'autant plus viscéraux qu'il paraît menacé (et avec lui tout ce qu'il symbolise). Le discours sur le risque de disparition du livre papier va de fait de pair avec celui qui déplore une baisse de la lecture (littéraire), voire une crise de la culture (légitime)

L'écran (des ordinateurs, tablettes et smartphones, après celui du cinéma et de la télévision) est posé comme le concurrent du livre, celui qui, dans une logique de division de l'attention et de partage du temps libre, nuirait forcément à la lecture (ou du moins à la "vraie lecture »). Comment dès lors envisager la possibilité d'une lecture sur écran ? N'est-ce là qu'un oxymore marquant

l'impossibilité de la pratique?

\section{Lire en numérique, est-ce vraiment lire ?}

Les essayistes, qui raisonnent sur un « lecteur » abstrait plus qu'ils n'observent la réalité des pratiques, posent d'emblée la lecture numérique comme une pratique de valeur inférieure : lire sur écran, est-ce encore lire ? La « vraie lecture » peut-elle vraiment se pratiquer sur un autre support que le livre imprimé ? En d'autres for Books: Past, Present and Future" (Darnton 2011); "Against Digital Colonialism: Manifesto to Keep on Reading" (Casati 2013); “The Havoc of Screens" (Spitzer 2019).

Discourse about "the digital sphere" gathers many different types of digital technology into this expression, without distinguishing between them, which leads to hasty and sometimes excessive generalizations. The digital can only be understood in relation to paper books and the value conferred to them. Paper books have become the symbol of culture-a humanist, literary, and often vaguely defined culture-and elicit attachment that becomes all the more visceral as they appear to be threatened (along with their attached symbolism). Discourse on the risk of paper books disappearing in fact goes hand in hand with discourse that deplores a decrease in reading (literature), and perhaps even a crisis of (legitimate) culture.

Screens (of computers, tablets, and smartphones, just as was the case for cinema and television) are seen as competitors to books. They allegedly threaten reading (or at least "real reading"), by diverting attention and claiming free time that could otherwise be used for reading. In this light, how are we to conceive of on-screen reading? Is it just an oxymoron indicating the impossibility of such a practice?

\section{Is Digital Reading Really Reading?}

Essayists who reason with an abstract "reader," rather than actually observing the reality of practices, evaluate digital reading as an inferior practice from the outset. Is on-screen reading still reading? Can "real reading" be practised on a medium other than a printed book? In other words, can we practise long, in-depth and disinterested reading digitally? 
termes, peut-on pratiquer en numérique une lecture longue, approfondie et désintéressée?

Les effets négatifs censés résulter « des écrans » (diminution de la capacité d'attention et de concentration, baisse des performances cognitives, fermeture sur soi et diminution du sentiment d'empathie) (Spitzer 2019) semblent s'inscrire en complète opposition aux qualités que la lecture, notamment la lecture littéraire, est réputée développer etpour lesquelles elle estencouragée. La lecture littéraire est notamment valorisée pour sa capacité à accroître l'expérience du lecteur ou de la lectrice, dans le sens de l'élargissement mais aussi de l'approfondissement, parce que la litérature décortique des phénomènes qui, dans le flux du quotidien, échappent bien souvent à sa perception (voir Nussbaum 1990, Bouveresse 2008, Laugier 2006). Qu'advient-il quand cette lecture, qu'on associe à la culture, est pratiquée sur écran ?

Le côté « technique » du numérique porte-t-il à lui associer plus volontiers des lectures utilitaires, professionnelles ou didactiques ? Apparaît-il « froid » et à cet égard antagonique à une lecture esthète qui met l'accent sur la sensibilité du lecteur et de la lectrice et qui semble s'associer plus immédiatement à la matérialité de l'objet livre tel que décrit par Michel Melot (Melot 2006) ? Maint·e·s lecteur.rice·s décrivent en effet leur attachement au toucher du papier ou à l'odeur de l'encre, et se disent attentif.ve.s aux choix typographiques ou à la qualité de la fabrication. Cette hypothèse porterait à interroger le choix de certaines bibliothèques de proposer sur liseuses une offre exclusivement constituée de classiques de la littérature française, dont la valeur est réputée résider dans le travail de la forme au moins autant que dans le propos

Si la lecture numérique est souvent décriée par les chercheur·se·s en littérature, ce serait en raison de leur croyance dans les
The negative effects allegedly caused "by screens" (a decrease in attention and concentration capacity, lowered cognitive performance, isolation and decreased empathy) (Spitzer 2019) seem to be in complete opposition to the qualities that reading, specifically literary reading, is deemed to develop and for which it is encouraged. Literary reading is notably valued for its capacity to increase the reader's experience, widening and deepening it, because literature unpacks phenomena which often escape perception in the flow of everyday life (see Nussbaum 1990; Bouveresse 2008; Laugier 2006). What happens when this reading, associated with culture, is practised on a screen?

Does the "technical" side of digital mediums lead them to being more easily associated with utilitarian, professional, or didactical reading? Does it seem "cold" and thus antagonistic to a more aesthetic reading practice which emphasizes readers' sensitivity and seems more readily associated with the book's materiality as an object, as described by Michel Melot (Melot 2006)? Many readers indeed express their attachment to the feeling of paper or the smell of ink and claim to be attentive to font choices or manufacturing quality. This hypothesis would lead us to question the choice certain libraries make to offer e-readers exclusively filled with French classics, whose value is deemed to reside in their form at least as much as in their content.

Researchers in literature often deplore digital reading because of their belief in the virtues of "close reading." They indeed consider 
vertus d'une « lecture rapprochée »: ils/elles considèrent en effet comme la seule lecture proprement littéraire cette lecture lente et attentive à la langue, que tente de construire l'enseignement de la littérature à l'université et au lycée (voir Renard 2011). C'est la thèse défendue par Katherine Hayles : "Tant que cette croyance exerce son emprise, la lecture numérique sera perçue au mieux comme périphérique par rapport à nos préoccupations principales, repoussée dans les marges comme n'étant pas "véritablement" de la lecture ou en tout cas pas de la lecture intéressante ou attirante »(Hayles 2016 : 126). John Guillory oppose ainsi la " lecture rapprochée » et la lecture rapide pratiquée sur support numérique (Guillory $2010: 8$ ), comme si la lecture rapprochée ne pouvait se pratiquer sur support numérique.

\section{Une lecture de survol ?}

Le numérique fait-il vraiment lire autrement ? Par la quantité de textes disponibles et reliés, favorise-t-il la lecture rapide et l'appréhension d'un grand nombre de documents, selon ce que Dominique Boullier propose de nommer " lecture indicielle ", qui permet de " connaître peu de beaucoup » (Boullier 2011 : 51) et qui n'est pas sans évoquer la pratique du bibliothécaire de Musil dont le secret professionnel, pour bien maîtriser ses fonds, consiste à ne surtout pas se laisser tenter par la lecture in extenso d'aucun volume particulier (Musil 2004 : 553) ? Favorise-t-il, selon ce que suggère Christian Vandendorpe, un cheminement plus personnalisé et potentiellement plus riche, une « lecture extensive » suivant un mode « tabulaire » qui prélève des informations choisies parmi un ensemble de possibles, par opposition à la " lecture intensive ", linéaire et attentive à saisir toutes les articulations du texte, à laquelle prêterait le texte dépourvu de renvois (qu'il s'agisse d'hypertextes ou de notes) ou de documents voisins (iconographiques ou textuels) (Vandendorpe 1999)? this slow form of reading, which is attentive to language and is taught in university and secondary school literature classes (see Renard 2011), as the only true literary reading. This is the point of view that Katherine Hayles holds: "As long as this belief still holds, digital reading will be seen at best as peripheral compared to our main preoccupations, deferred to the margins as not 'really' reading or at least not interesting or attractive reading" (Hayles 2016: 126). John Guillory thus opposes "close reading" to fast reading practised on a digital medium (Guillory 2010: 8), as though close reading could not be practised on a digital medium.

\section{Skim Reading?}

Does digital technology really make us read differently? Does seeing the number of books available and the links between them favour fast reading and the apprehension of a large number of documents, through skim reading which, according to Dominique Boullier, enables the reader to know "a little about a lot of things" (Boullier 2011: 51) and evokes the practices of Musil's librarian, whose professional secrecy consisted in never being tempted into reading a single volume in extenso in order to handle his collection (Musil 2004:553). Does it favour a more personalized and potentially richer progression as suggested by Christian Vandendorpe, an "extensive reading" in a "tabular" mode which selects chosen information from amongst a number of possibilities? This is opposed to a linear, "intensive reading," attentive to the text's subtleties, allegedly because there are no references (either hyperlinks or notes) or neighbouring documents (either iconographic or textual) (Vandendorpe 1999). 
Dans les faits, le numérique pousse-t-il au survol, à l'abandon ou à l'errance, comme le supposent ses détracteur.rice-s ? Engendre-t-il des formes de dispersion de l'attention nuisibles à la compréhension (Wolf 2007 ; Mangen, Walgermo, Brønnick 2013) ? Rend-il plus difficile le retour en arrière, la vérification, la possibilité de retrouver un indice ou un passage repéré, et, partant, la mémorisation de l'information notamment parce que celle-ci est mobile sur le support, donc impossible à localiser visuellement ou tactilement, grâce à la perception de l'épaisseur du livre ? C'est ce que tendraient à prouver diverses expérimentations menées en lien avec les neurosciences, dont nous tenterons de donner ici un

rapide aperçu.

Ainsi, des études neurologiques menées par Thierry Baccino et Véronique Drai-Zerbib au Laboratoire des usages en technologies numériques ont analysé, d'une part, les présupposés des dispositifs de lecture sur support numérique et sur support papier (ce qu'ils requièrent en termes d'attention, de navigation, de mise en relation) et, d'autre part, les usages de ces deux types de supports (Baccino \& Drai-Zerbib 2015). Des expérimentations fondées notamment sur une étude des mouvements de l'œil complétée par des questions posées à l'utilisateur.rice leur permettent d'établir la manière dont il/elle perçoit l'information, l'attention qu'il/elle prête aux différents éléments présents sur une page, sa capacité à comprendre et à mémoriser cette information. Le passage du papier au numérique semble plutôt défavorable au numérique : l'attention est moindre,

la compréhension moins bonne, la mémorisation plus restreinte.

La structure hypertextuelle semble, au moins en partie, responsable de ce phénomène. Des études montrent ainsi qu'une différence dans la compréhension d'un texte s'observe (quel que soit le support) selon qu'il est proposé en version linéaire ou dans une version enrichie de liens hypertextes (Zhu 1999 ; Miall \& Dobson
Do digital texts in actual fact encourage skim reading, discontinuation, and diversion from the text, as their detractors claim? Do they engender forms of attention diversion which harm understanding (Wolf 2007; Mangen, Walgermo, Brønnick 2013)? Do they make it harder to go back to verify something, to find a clue or a specific passage, and, in the end, to memorize the information because it is not fixed on the device and thus impossible to locate visually or through touch using the reader's perception of the book's thickness? This is what various neuroscientific experiments tend to prove, and we shall try to give a brief overview of them here.

Thus, neurological studies carried out by Thierry Baccino and Véronique Drai-Zerbib at the Laboratory for Uses in Digital Technology analysed, on the one hand, the assumptions of reading facilities on digital and paper mediums (what they require in terms of attention, navigation, relation, etc.) and, on the other hand, the uses of these two types of medium (Baccino \& Drai-Zerbib 2015). Experiments founded notably on a study of eye movements followed by questions put to users allowed them to establish the way in which users perceive information, the attention paid to the different elements present on one page, and their capacity to understand and memorize a piece of information. Going from paper to digital mediums appears to be rather unfavourable to digital devices: attention decreases, understanding weakens, and memorization becomes more restricted.

Hyperlinks seem in part responsible for this phenomenon. Studies thus show that a difference in the understanding of a text can be observed (whatever the medium) according to whether it is offered in a linear version or one enriched with hyperlinks (Zhu 1999; Miall \& Dobson 2001): hyperlinks call upon working memory, and thus 
2001) : les hypertextes sollicitent la mémoire de travail, qui ne peut par conséquent engranger autant d'autres informations qu'elle le ferait avec un texte linéaire, de sorte que la compréhension globale est moins bonne quand les hypertextes sont plus nombreux (Hayles $2016: 133)$

D'autres études donnent une vision plus positive de la lecture numérique, en montrant qu'elle active des zones du cerveau liées à la prise de décision et au raisonnement complexe, moins sollicitées par la lecture sur support imprimé (Centre de recherche sur la mémoire et l'âge, cité par Guillaud 2010 : 23). Toutefois, le phénomène semble moins lié au support numérique en soi qu'à la manière dont l'information est organisée sur le web, en mode tabulaire plutôt que linéaire, amenant l'utilisateur-rice à un constant travail d'évaluation, de sélection et de mise en relation. Certaines études neuroscientifiques affirment ainsi que ce n'est pas le passage du papier à l'écran qui modifie les perceptions et les usages, mais plutôt les diverses fonctionnalités que propose aussi l'écran, les prises de décision qu'il impose, les distractions ou tentations qu'il offre : les possibilités de navigation, de commentaire, de partage, voire les possibilités complètement extérieures à la lecture ellemême incluses sur le même support, requièrent en effet une discipline particulière de la part de l'utilisateur.rice désireux-se de se concentrer de manière prolongée sur le texte proprement dit

(Cohen 2009 ; Dehaene 2007)

II importe par conséquent de distinguer ce qui tient au support proprement dit et ce qui renvoie à l'organisation des contenus. Le modèle de la page web (avec des blocs de textes, articulés avec des images ou des vidéos, et enrichis d'hyperliens) est souvent utilisé pour penser l'organisation des contenus sur support numérique : on associe volontiers le papier à une forme de finitude, que le numérique viendrait rompre en proposant des cannot reap as much other information as a linear text would, which results in a decrease in general understanding when hyperlinks are more abundant (Hayles 2016: 133).

Other studies result in a more positive vision of digital reading, showing that it activates zones of the brain that are linked to decision-making and complex reasoning that are less called upon when reading on printed mediums (Centre de recherche sur la mémoire et l'âge, cited by Guillaud 2010: 23). Nevertheless, the phenomenon seems to be less linked to the digital medium itself than to the way in which information is organized on the web, in tabular rather than linear mode, forcing the user to constantly evaluate, select, and link. Certain neuroscientific studies thus state that what changed perceptions and uses was not the passage from paper to the screen, but rather the different functions that the screen also offers, the decision-making process that it imposes, the distractions or temptations that it offers. Browsing possibilities-commenting, sharing, even possibilities that are completely disconnected from reading which are nonetheless included in the medium-indeed require a specific kind of discipline on users' behalf if they want to concentrate on the actual text for a length of time (Cohen 2009; Dehaene 2007).

It is thus important to distinguish the specific characteristics of the medium itself and the content organization. The web page model (with block texts, displayed alongside images or videos, and enriched with hyperlinks) is often used in order to create and organize online digital content: paper is readily associated with a type of finitude, with which the digital marks a break by proposing quasi-infinite possibilities of extension and referral, notably via 
possibilités quasi infinies d'extension et de renvoi, notamment via les hypertextes. Mais aucune organisation de contenu n'est inhérente au numérique : la liseuse tend par exemple à reproduire l'organisation du livre papier et des pages qui le composent et, à l'inverse, la complexité de la page web se retrouve largement dans les manuels scolaires imprimés tels que les maisons d'édition les conçoivent aujourd'hui (Bonnéry 2015).

Qu'en est-il de la lecture sur un dispositif connecté à internet, qui permet à la fois un accès immédiat à une multitude d'informations et de sources, mais aussi des possibilités de partage immédiat par mail ou via les réseaux sociaux ? Qu'en est-il à l'inverse des formats numériques homothétiques du papier, à l'instar d'un document numérisé d'une bibliothèque patrimoniale ou même de la version pdf d'un article scientifique (qu'il peut d'ailleurs arriver au chercheur ou à la chercheuse d'imprimer) ? On voit bien à travers ces exemples la nécessité de distinguer les formes et les formats, mais aussi l'ensemble des propriétés et fonctions des dispositifs

numériques.

L'histoire du livre, par l'attention qu'elle a portée aux effets des objets et des formes, invite ainsi à déconstruire l'hyperonyme " numérique » pour considérer l'hétérogénéité des supports qu'i englobe, de l'ordinateur à la liseuse en passant par le smartphone et la tablette, et des formats, du billet de blog au livre numérique : on ne lit pas de la même manière un article de presse, un article scientifique ou un roman, fût-ce sur un support numérique. Selon la nature du texte, l'attention est différente, plus ou moins constante et profonde. C'est aussi que la perspective qui anime la lecture et qui l'oriente n'est pas la même. Elle varie en outre selon le sujet traité et l'intérêt qu'on y porte. Si ces variations sont déjà bien établies, quels effets produisent les différences de support ? Qu'est-ce qui change selon qu'on lit un texte donné sur papier ou hyperlinks. But no content organization is inherent to digital media. E-readers, for instance, tend to reproduce the organization of paper books and the pages that they are composed of, and, conversely, the complexity of web pages can largely be found in printed schoolbooks such as they are designed by publishing houses nowadays (Bonnéry 2015).

What about reading on a device connected to the internet, which allows for instant access to a wide array of information and resources, as well as immediate sharing possibilities by email or social media? And, conversely, what about digital formats that mimic paper formats, such as scanned documents from an archive or even the PDF versions of a scientific paper (that the researcher in fact might even print)? These examples point towards the necessity of identifying forms and formats, as well as the whole range of properties and functions on digital devices.

Through the attention that it has given to the effects of objects and forms, the history of books thus invites us to deconstruct the hypernym "digital" and consider the heterogeneity of mediums that it comprises, from computers to readers through smartphones and tablets, and of formats, from blog posts to e-books: we do not read a press article, a scientific article and a novel in the same way, even on a digital medium. Depending on the nature of the text, our attention is different, more or less constant and in depth. Also, the perspective that motivates and orientates reading is not the same. What is more, reading varies according to subject matter and the reader's interest. If these variations are already well established, what effects result from different mediums? What changes when reading a text on paper from when reading on a digital device 
sur support numérique (voir Guillaud 2010), et selon qu'on utilise une tablette rétroéclairée, une liseuse à encre électronique, un smartphone ou un ordinateur ? Qu'est-ce qui, à cet égard, tient au support proprement dit ou aux nouvelles possibilités formelles permises par le support?

\section{D'autres supports pour d'autres objets de lecture?}

Quelle est la réalité des pratiques de lecture numérique ? Le numérique fait-il lire des personnes qui ne lisaient pas sur papier ? Modifie-t-il les pratiques de celles qui lisaient déjà sur papier ? Et si oui, en quel sens ? Les enquêtes quantitatives sur la lecture prouvent la coexistence de pratiques de lecture numérique avec la lecture sur papier, y compris chez les mêmes lecteur.rice·s, dans une logique de cumul souvent attestée dans les études de sociologie de la culture (Coulangeon \& Lemel 2009). Une enquête publiée en juin 2018 révélait ainsi que $35 \%$ des 15-25 ans interrogé·e.s affirmaient lire leurs livres à la fois sur papier et sur support numérique (contre seulement $2 \%$ de lecteur.rice.s exclusif.ve.s de livres numériques mais $47 \%$ de lecteur.rice-s exclusif-ve-s de livres imprimés) (Vincent Gérard \& Vayssettes 2018). Quel(s) intérêt(s) ces lecteur.rice-s trouvent-ils/elles au numérique?

Lisent-ils/elles sur numérique autre chose qu'en imprimé, ou dans d'autres circonstances - comme le suggère la cohabitation fréquente des deux pratiques chez les mêmes individus ? Quelle relation la lecture sur support numérique entretient-elle, chez le/la lecteur.rice, avec la lecture sur support papier ? S'inscrit-elle dans une logique d'opposition et de concurrence comme le suggèrent les discours qui invoquent le numérique comme un des facteurs de la « crise de la lecture » ou de la «mort du livre »? S'inscritelle seulement dans une logique de substitution de support, qui ne (see Guillaud 2010), and what effect does using a backlit pad, an electronic ink e-reader, a smartphone or a computer have? In this regard, what is owed to the actual medium and what is owed to the new formal possibilities the medium allows for?

\section{Other Mediums for Other Reading Purposes?}

What is the reality of digital reading practices? Does digital technology make people who did not usually read on paper do so? Does it change the practices of those who already read on paper? If so, in what way? Quantitative studies on reading prove the coexistence of digital reading practices alongside reading on paper, even on the same reader, in a cumulative logic often attested to in the sociology of culture (Coulangeon \& Lemel 2009). A survey published in June 2018 thus revealed that $35 \%$ of $12-25$-year-old interviewed confirmed that they read their books both on paper and on digital devices (compared with a mere $2 \%$ of readers exclusively reading digital books and $47 \%$ reading exclusively printed books) (Vincent Gérard \& Vayssettes 2018). What advantages do these readers see in digital mediums?

Do they use digital devices to read something other than what they read on paper, or in other circumstances-as suggested by the frequent occurrence of both practices in the same individual? What is the relationship between reading on a digital medium and reading on paper? Is it inscribed in a logic of opposition and competition, as suggested by discourse which invokes digital technology as one of the factors for the "reading crisis" or the "death of books"? Is it simply inscribed in a medium substitution logic, which does not radically change the practice, but leads to a quasi-transposition of 
modifie pas radicalement la pratique, mais conduit à une quasitransposition des mêmes usages du papier au numérique ? Vientelle plutôt prolonger la lecture sur papier dans une logique de cumul en apportant d'autres profits que celle-ci et en permettant d'autres usages sociaux ou en favorisant certains usages plus que d'autres (Mauger \& Poliak 1998)?

L'écart entre les chiffres de vente et les données sur la lecture tendent à prouver que la lecture numérique ne porte que de manière encore assez restreinte sur des textes achetés. En effet, le livre numérique ne constitue aujourd'hui encore en France qu'une faible part des ventes $(7,6 \%$ du chiffre d'affaire des ventes de livres en 2017 selon les chiffres clés produits par le service Livre et lecture du ministère de la Culture qui précisent aussi que seuls 4,4\% des Français ont acheté en 2017 au moins un livre numérique). Mais la sociologie de la lecture a depuis longtemps souligné la non-coïncidence des pratiques d'achat et de lecture, certains livres achetés n'étant jamais lus, et, réciproquement, certains livres lus n'étant jamais achetés mais empruntés ou reçus par d'autres voies (voir Renard 1995 ; Rouet 1995 ; Guittet 2018). Le numérique réduit sans doute la possibilité de l'achat pour autrui, par rapport à un livre papier qui occupe une place de choix parmi les cadeaux, mais il accroît les possibilités de piratage. II est donc susceptible de donner accès à la lecture de textes que l'on n'aurait pas achetés. Le support numérique permet-il ainsi de lire des écrits qu'on ne lisait pas sous forme de livres, par exemple en raison du coût de ces derniers (qu'on ne pouvait pas ou ne voulait pas investir), ou de leur accessibilité réduite (livres introuvables ou difficiles d'accès, fonds patrimoniaux désormais numérisés, etc.) ? Les enquêtes quantitatives montrent aussi de forts écarts selon les secteurs (voir Legendre 2019), les livres pratiques ou les romans sentimentaux étant par exemple beaucoup plus présents dans les ventes en numérique que la littérature générale. Ce phénomène the same uses from paper to digital format? Or does it prolong reading on paper in a cumulative logic through other advantages, permitting other social uses or favouring certain uses over others (Mauger \& Poliak 1998)?

The gap between sales figures and data on reading tends to prove that digital reading hardly concerns bought texts. Indeed, digital books only constitute a small amount of sales in France today (7.6\% of book sales revenue in 2017 according to key figures produced by the Ministry of Culture's Book and Reading Service, which also adds that only $4.4 \%$ of French people bought at least one digital book in 2017). But the sociology of reading has long underlined the non-coincidence of buying practices and reading practices, as some bought books are never read, while, conversely, some books are never bought but borrowed or acquired through other means (see Renard 1995; Rouet 1995; Guittet 2018). Digital technology certainly reduces the possibilities associated with buying books as gifts for others, compared with paper books which occupy a place of choice amongst gifts. However, it increases possibilities for pirating. Digital mediums therefore allow access to texts that would otherwise not have been bought. Do digital mediums thus encourage users to read texts that were not previously read in paper format, due, for instance, to their price (that one could not or would not invest), or to their reduced accessibility (books that were difficult to find or access, archive material that has been digitized, and so on)?

Quantitative studies also show wide gaps according to editorial sectors (see Legendre 2019), as practical books or romance novels, for instance, are much more present in digital sales than general literature. Does this phenomenon owe to questions of 
tient-il à des questions de légitimité ? Le numérique favoriserait-il la lecture de textes moins légitimes ? Si oui, cela tient-il uniquement aux modes de diffusion et de distribution de ces textes ? Ou en évitant d'exposer la couverture de l'objet lu, et donc des marques de genres ou de maisons d'édition qui peuvent jouer comme des marqueurs de classe, voire des stigmates, le numérique assure-t-il une forme de confidentialité plus propice aux textes avec lesquels

le/la lecteur.rice n'aimerait pas s'afficher?

De manière plus générale, un support numérique comme une liseuse participe-t-il à minimiser le poids de "l'énonciation éditoriale " (Souchier 1996) dans la construction du sens de l'œuvre par le/ la lecteur.rice ? Le paratexte, notamment éditorial, joue en effet un rôle important dans la manière dont les lecteur.rice.s perçoivent le texte (Genette 1987). Ce paratexte est constitué par l'appareil qui, dans le livre, entoure le texte et l'accompagne (préface, notes, bibliographie de l'auteur.rice, etc.) mais surtout par la couverture du livre (titre, graphisme, iconographie, texte de quatrième de couverture), qui n'est pas constamment affichée sur support numérique. Cette disparition de la couverture peut d'ailleurs jouer en sens inverse en restreignant les profits de distinction que pouvait trouver le/la lecteur.rice à s'afficher avec tel ouvrage ou le faire figurer dans sa bibliothèque (voir Mauger, Poliak, Pudal 1999). Ou encore réduire les effets prescripteurs potentiellement produits par le fait de voir quelqu'un lire tel ou tel livre (voir Casati 2013 : 16).

II existe par ailleurs des formes inédites dont le numérique a permis l'avènement. Si le numérique participe à " configurer les scripturalités » (Paveau 2015), à quelles lectures donne-t-il lieu ? Qu'en est-il par exemple de la lecture de textes " augmentés ", c'est-à-dire qui intègrent des possibilités nouvelles (liens vers d'autres textes, image et notamment image animée, son, etc.) ? Qu'en est-il des possibilités d'écriture collaborative, de legitimacy? If so, is it simply due to these texts' distribution modes? Or do readers want to avoid exposing the book cover, and thus the genre or publishing house label, which can act as social class or social stigma markers? Do digital devices ensure a kind of more appropriate confidentiality for the kinds of text that readers would not like to be seen with?

More generally, do digital mediums such as e-readers help to minimize the weight of "editorial enunciations" (Souchier 1996) in readers' construction of the work's meaning? Paratexts, notably editorial ones, indeed play an important role in the way in which readers perceive texts (Genette 1997). Paratexts in books are constituted by means of framing and accompanying a text (preface, notes, author's bibliography, etc.), but especially by the cover (title, graphics, iconography, and back cover blurb), which is not constantly displayed on digital devices. This disappearance of the cover can also play in the opposite direction, restricting the profits of distinction derived from being seen with such and such a book or displaying it in one's library (see Mauger, Poliak, Pudal 1999). Or else reducing the probability of deciding to read a book after simply seeing someone else reading it (see Casati 2013: 16).

Furthermore, unprecedented forms of text have sprung up thanks to digital technology. If digital technology contributes towards "configuring scripturalities" (Paveau 2015), what kind of reading does it give rise to? What about the reading of "enhanced" texts, which integrate new possibilities (links towards other texts or images and specifically animated images, sound, etc.)? What about the possibilities for collaborative writing, restructuring, and 
recomposition, d'appropriation permises par certains nouveaux formats ? Le lectorat de ces formes renouvelées est-il constitué seulement d'autres scripteur-rice-s ou de lecteur-rice-s ordinaires ? Lit-il exclusivement ces formes nouvelles ou prête-t-il aussi attention à des formes de création sur support imprimé ? Les créations numériques sont-elles aujourd'hui le lieu de l'avant-garde

littéraire?

\section{Fonctionnalités intégrées et usages anticipés}

Le numérique offre non seulement du texte mis en forme mais aussi des fonctionnalités permettant son appropriation (feuilletage, copie, annotation, etc.). Certaines sont moins des innovations que des transpositions de gestes effectués, au moins par une partie du lectorat, sur le livre imprimé. Sont-elles d'autant plus investies qu'elles reproduisent des gestes déjà familiers ? Par exemple, par quel·le·s lecteur·rice·s les systèmes de prise de note intégrés sontils mobilisés ? À quel type de pratique d'écriture donnent-ils lieu ? Les supports numériques intègrent aussi des outils de type dictionnaire ou liens hypertextes qui lèvent les éventuelles difficultés lexicales ou référentielles du texte. Permettent-ils une compréhension plus aboutie ou plus précise ? Certes le/la lecteur-rice d'imprimé pouvait déjà consulter des notes de bas de page ou des usuels pour lever des doutes qui surgissaient lors de la lecture. La facilité d'accès à l'information complémentaire favorise-t-elle son appréhension ? Le/la lecteur-rice consulte-t-il/elle la définition d'un mot plus souvent que lorsqu'il/elle avait à interrompre sa lecture pour se tourner vers un dictionnaire?

Si la dématérialisation des fichiers fait disparaître la trace matérielle des lectures et le support mémoriel que constitue la bibliothèque physique d'un individu ou d'un foyer (voir Mauger, Poliak, Puda 1999), les bibliothèques virtuelles assurent-elles un semblable rôle d'aide-mémoire ? La possibilité de recherche par mots clés appropriation permitted by certain new formats? Is the readership of these renewed forms only made up of other writers or also of ordinary readers? Do readers only read these new forms, or do they also pay attention to creative formats on printed mediums? Are digital creations today's space for the new literary avant-garde?

\section{Integrated Functions and Anticipated Uses}

Digital technology not only offers formatted texts but also functions that allow users to personalize their text (turning pages, copying, note-taking, etc.). Some are less innovations than transpositions of gestures performed at least by some readers on printed books. Are they all the more invested because they are reproducing gestures that are already familiar? For instance, what kind of readers use note-taking systems? What kind of writing practice does this lead to? Digital mediums also integrate dictionary-type tools and hyperlinks that ease any potential lexical or referential difficulties in the text. Do they allow for a more complete and precise understanding of the text? Admittedly print readers could already consult footnotes or reference books in order to clarify any doubts that might have come up while reading. Does easier access to complementary information encourage users to consult it? Do readers check definitions more often than when they had to interrupt their reading to reach for a dictionary?

If the dematerialization of files is making the material trace of reading and the memorial medium constituted by an individual's or a household's physical library disappear (see Mauger, Poliak, Pudal 1999), do virtual libraries also play a similar memory-aid role? Does the possibility of keyword or text search facilitate browsing 
ou mots du texte dans ces bibliothèques numériques facilite-t-elle la navigation parmi les livres déjà lus et pour partie oubliés (voir Bayard 2006) ? Ou l'expérience du numérique s'inscrit-elle dans une temporalité éphémère où chaque lecture remplace et efface la précédente, à la manière dont le texte s'efface de l'écran ?

Les outils intégrés à certains dispositifs numériques vont-ils jusqu'à engendrer des usages nouveaux ? Si l'outil numérique ne semble pas suffire à créer le désir de lire et à initier la pratique de lecture (Barbagelata, Inaudi, Pelissier 2014), se met-on par exemple à prendre des notes ou à surligner alors qu'on n'aurait jamais osé le faire sur un livre papier sacralisé ? Ou à lire en langue originale parce que le dictionnaire intégré permet de trouver en un clic le sens des mots inconnus? Des personnes qui avaient interrompu leur pratique de lecture en raison de problèmes de vue peuventelles renouer avec cette pratique grâce aux fonctionnalités de grossissement offertes par exemple par la liseuse ?

Au-delà de leurs usages réels, ces fonctionnalités ont-elles aussi une vertu symbolique par les possibles, au moins théoriques, qu'elles ouvrent ? II n'est pas impossible que le seul fait de pouvoir faire (et savoir qu'on peut) joue parfois autant que la pratique ellemême. Posséder une bibliothèque, c'est non seulement avoir des livres à lire, mais savoir qu'on a des livres à lire ; de même choisir le format numérique, c'est savoir qu'on aura sous la main une grande quantité de textes (excédant largement ce qu'on pourra lire) et qu'on pourra (pourrait) les mettre en relation avec d'autres, en approfondir à l'infini la lecture, voire intervenir dans le champ littéraire comme médiateur critique susceptible d'avoir des effets sur la production elle-même.

Observe-t-on des usages conformes à ce qui a été imaginé par les concepteurs ou, au contraire, des formes de détournement through previously read books that have been in part forgotten (see Bayard 2006)? Or is the experience of digital reading inscribed in an ephemeral temporality in which each text read replaces and erases the former, in the same way as texts disappear from the screen?

Do the tools integrated into some digital devices go so far as to generate new uses? If digital tools do not seem to be enough to create the desire to read and initiate reading practices (Barbagelata, Inaudi, Pelissier 2014), do we for instance start taking notes or highlighting although we would never have dared to do so in a sacrosanct paper book? Or read a book in its original language because the integrated dictionary allows us to find the meaning of unfamiliar words with one click? Can people whose reading habits have been interrupted by eyesight problems return to it thanks to the font magnification functions provided, for instance, by e-readers?

Beyond these real uses, do these functions also have symbolic value simply because of the theoretical possibilities they open up? Possibly the simple fact of having the option to do something (and knowing that one can) plays a part as much as the practice itself. Having a library means not only having books to read, but also knowing that one has books to read. Likewise, choosing a digital format means knowing that one has a large number of texts at hand (which largely exceeds what one will be able to read). Thus, one will (or would) be able to link them with other texts, deepen the reading endlessly, or even intervene in the literary field as a critical mediator, which could itself have repercussions on actual production.

Can we observe uses that conform to what was imagined by the designers of these facilities or, conversely, forms of 
des dispositifs ? Nombre d'études, notamment en sciences de l'information et de la communication, se centrent en effet sur les usages permis a priori par tel ou tel dispositif. Madeleine Akrich propose ainsi de considérer qu'un " script » est inscrit dans le design de l'objet technique : celui-ci intègre des scénarios d'usage anticipés, que l'utilisateur-rice pourra suivre ou parfois contourner/ détourner, mais qui déterminent en partie l'espace des possibles (Akrich 1987). Dans cette optique, certains travaux sur la lecture numérique se centrent sur le lecteur ou la lectrice supposé·e.s par les éditeur.rice-s et designers d'objets et formats numériques (Tréhondart 2014 ; Saemmer 2015). Qu'en est-il de la réalité des usages, par rapport aux usages et usager-ère·s postulé.e.s ? Les appropriations des dispositifs varient-elles en fonction de l'habitus des lecteur.rice.s?

\section{Pour des sciences sociales des usages du numérique}

Seule l'enquête empirique peut permettre de sortir d'un discours abstrait pour tenter d'établir les représentations et les usages des dispositifs, et surtout d'en saisir les logiques et de comprendre les principes de différenciation qui tiennent aux dispositifs eux-mêmes mais aussi à d'autres paramètres. L'approche neurobiologique présente l'intérêt de reposer sur des études expérimentales précises, utilisant des techniques sophistiquées allant de l'eyetracking à l'imagerie cérébrale. Mais elle constate les usages sans, le plus souvent, pouvoir en rendre compte. Elle met par ailleurs peu en avant les variations sociales constatées entre les sujets de l'expérimentation. Or, quelques rares enquêtes établissent des différences entre les lecteur.rice.s qui ne tiennent pas seulement à l'âge ou à l'appartenance générationnelle, mais renvoient à des rapports différenciés à la technique, à l'offre culturelle et au « numérique » comme catégorie symbolique (Boullier \& Crétel misappropriation? Many studies, especially in information and communication sciences, indeed centre on the uses that are a priori allowed for by certain devices. Madeleine Akrich thus suggests considering that a "script" is inscribed in the technical object's design: it integrates anticipated use scenarios that the user could follow or sometimes transform, but that in part determine the space of possibilities (Akrich 1987). In this view, some studies on digital reading centre around the reader hypothesized by the editors and designers of digital objects and formats (Tréhondart 2014; Saemmer 2015). What about the reality of uses, compared with the imagined users? Do the appropriations of facilities vary according to readers' habitus?

\section{For a Social Science of Digital Uses}

Only empirical studies allow us to depart from abstract discourse and try to establish the representation and use of such devices. They especially help to grasp the logic that underpins the use of devices and understand the differentiation principles that are owed not only to the devices themselves but also to other factors. The neurobiological approach is interesting in that it is based on precise experimental studies which use sophisticated techniques ranging from eye-tracking to brain imagery. But this approach observes uses without usually being able to account for them. Furthermore, it scarcely emphasizes social variations observed between the subjects of a study. Yet some rare studies establish differences between readers which are not only age-based or generational, but to different relationships to technology, to cultural background and to "the digital sphere" as a symbolic category (Boullier \& Crétel 2013). It remains for us to study mediums and readers in their full 
2013). Reste à étudier les supports et les lecteur.rice-s dans leur diversité, en utilisant les outils des sciences sociales, de manière à tenter de comprendre ce qui se joue dans ces usages et nonusages du numérique. Quelles variations observe-t-on d'un·e lecteur.rice à l'autre et à quelles variables relier ces variations ?

Quel est le rôle de l'environnement, professionnel, familial ou amical, dans l'adoption du support numérique pour la lecture et dans son appropriation ? On connaît l'importance des pairs et des prescripteurs dans les choix d'objets de lecture (voir Guittet 2018). Comment joue-t-elle dans l'adoption de la lecture sur support numérique? La présence d'early adopters dans le cercle de pairs conduit-elle à la diffusion de la pratique par imitation ou initiation (voir Miguet 2014) ? Comment les représentations, socialement construites, de la technique mais aussi de la lecture (avec les valeurs et les normes qui leur sont associées) interviennent-elles dans l'appropriation des dispositifs (voir Paquienséquy \& Miguet 2015) ?

Quelles variations d'usage tiennent au degré de familiarité avec le support («le numérique » ou le dispositif numérique spécifique utilisé) ? Ce degré de familiarité tient-il en partie à la génération - avec de jeunes générations qui, par l'effet d'une socialisation numérique précoce (au smartphone, aux tablettes ou aux jeux vidéo), auraient développé des compétences numériques transposables d'un dispositif à un autre ? À l'inverse, le défaut de familiarité avec le numérique en général peut-il soit détourner des supports numériques (donc expliquer des non-usages) soit conduire à des usages avortés, c'est-à-dire à des expérimentations déceptives et donc sans lendemain?

Les « compétences de lecture numérique » sont-elles aussi corrélées à certaines formes de capital culturel, indépendamment diversity, using social science tools, in order to try to understand what is at stake in these uses and non-uses of digital technology. Which variations can we observe from one reader to the next, and what variables are these variations linked to?

What role do professional, family, and social environments play in the adoption and appropriation of a digital medium for reading? We understand the importance of peers and those who recommend reading choices (see Guittet 2018). How do these play into choosing to read on a digital device? Does the presence of early adopters in a peer group lead to the practice's dissemination through imitation or initiation (see Miguet 2014)? How do socially constructed representations of technology and reading (with the values and norms associated with them) intervene in the use of devices (see Paquienséquy \& Miguet 2015)?

To what extent are variations in use due to degree of familiarity with the medium (digital technology in general, or the specific digital device used)? Is this degree of familiarity in part generational - with younger generations who, thanks to an early digital socialization (with smartphones, tablets, or video games), may have developed digital skills that are transposable from one device to the next? Conversely, can a lack of familiarity with digital technology in general distract from digital mediums (and thus explain non-use) or lead to aborted uses, i.e. disappointing experiences never to be repeated?

Are "digital reading skills" also correlated with certain forms of cultural capital independent of the digital experience? Can we 
de l'expérience numérique ? Peut-on distinguer parmi elles une aisance technique qui serait propre au support (et peut-être augmenterait avec la socialisation précoce au numérique et avec l'expérience) et des compétences cognitives plus larges liées au maniement de l'écrit (perception de l'information, attention à la forme, prélèvement d'informations, mise en relation de données, construction d'hypothèses, raisonnement, mise en œuvre de stratégies pour plus d'efficacité, etc. - voir Goody 1978) ? Ces compétences cognitives seraient aussi à l'œuvre dans les pratiques extra-numériques et notamment dans la lecture sur support papier et se transposeraient sur support numérique avec de probables variations selon les caractéristiques sociales des lecteur.rice.s, ce qui permettrait de rendre compte des variations sociales observables dans les usages du numérique, y compris au sein d'une même génération réputée familière du numérique (voir

Mercklé \& Octobre 2012)?

L'enquête est certes difficile à mener. Les études sur la lecture numérique se confrontent aux mêmes difficultés que celles explorant la lecture de manière générale via des questionnaires ou des entretiens. Des effets de légitimité et de mise en scène de soi peuvent pousser à valoriser ou au contraire minimiser certaines pratiques (voir Mauger, Poliak, Pudal 1999). Surtout, l'enquêté·e a souvent oublié une partie de ce qu'il/elle a lu et, plus encore, ce qui a motivé tel ou tel de ses choix. Les outils numériques présentent à cet égard l'avantage de pouvoir garder des traces qui échappent à l'utilisateur-rice lui/elle-même, de ses cheminements, de ses tâtonnements, de ses recherches, de ses achats ou du temps qu'il/elle a passé sur tel objet ou telle opération. Collectées par les plateformes et « cookies » des sites, ces données ne sont encore que difficilement accessibles aux chercheur.se-s, ou le sont sans (heureusement) pouvoir être mises en relation avec d'autres données relatives aux caractéristiques sociales des individus. II distinguish a technical ease among them which may be mediumspecific (and may increase with early digital socialization and experience) and broader cognitive skills linked to handling writing (perception of information, attention to form, information collection, data linking, hypothesis construction, reasoning, using strategies for better efficiency, etc. - see Goody 1978)? Are these cognitive skills also at work in extra-digital practices, specifically in reading on paper, and transposed onto a digital medium with probable variations according to readers' social characteristics? This would account for social variations observed among digital media uses, included within the same generation known to be familiar with digital technology (see Mercklé \& Octobre 2012).

This investigation is admittedly a difficult one to carry out. Studies on digital reading face the same difficulties as those that explore reading in general through questionnaires or interviews. Legitimacy and self-staging effects can lead people to emphasize or downplay certain practices (see Mauger, Poliak, Pudal 1999). Above all, respondents have often forgotten part of what they have read, and, even more so, what motivated such and such a choice. Digital tools in this respect thus have the advantage of being able to keep a record of elements that escape users themselves, such as progress through a book, unfinished books, research, purchases, or time spent on a certain item or operation. Collected by platforms and site "cookies," these data are difficult to access for researchers, or are (thankfully) only accessible without links to other data pertaining to an individual's social characteristics. Research modalities that would allow for the collection of such information for scientific purposes still need to be invented. But only a survey, based on social science tools, would allow us to grasp their uses and logic. 
reste largement à inventer des modalités d'enquête qui permettent de récolter de telles informations à des fins scientifiques. Mais seule l'enquête, appuyée sur les outils des sciences sociales, permet de

saisir les usages et leurs logiques.

Le présent dossier se propose de réunir des travaux empiriques de sciences sociales permettant de saisir des pratiques et la distribution sociale de ces pratiques, mais surtout d'en mettre au jour les logiques. II s'agit donc moins de mesurer l'ampleur d'une " révolution » que toutes les études décrivent comme finalement plus mesurée, ou en tout cas moins radicale, que ce qu'on pouvait imaginer à l'orée du $\mathrm{Xxl}^{\mathrm{e}}$ siècle, que de tenter, à travers des études de cas précises, de saisir ce qui se joue dans l'usage, l'usage avorté ou le non-usage du numérique. II s'agit aussi de décentrer la focale des dispositifs eux-mêmes, vers les usages et donc les usager-ère-s, dans leur inscription sociale et dans leur diversité, contre de nombreux écrits qui ne considèrent qu'un Lecteur abstrait de tout contexte et de toute caractéristique sociale. Dans la pratique de lecture littéraire numérique, comment jouent et s'articulent les représentations qu'a l'usager-ère (du numérique, du livre, de la littérature, etc.), ses usages (appropriation, sélection, lecture, commentaire, partage, etc.), les processus cognitifs qu'il/elle met en œuvre lors de sa lecture (perception, sélection, mise en relation, mémorisation, compréhension, etc.), sa pratique plus globale au-delà de l'usage de ce dispositif (pratique lectorale, culturelle, intellectuelle, etc.) et les propriétés sociales qui caractérisent l'usager·ère (âge, génération, diplôme, classe sociale, groupe professionnel, genre, etc.) ? Que change en la matière le numérique par rapport à l'imprimé ?

Au-delà de la connaissance de l'évolution des pratiques de lecture, ce dossier vise à contribuer, à partir de données empiriques et d'analyses produites dans des cadres disciplinaires différents (de
The present dossier aims to bring together empirical studies from social science, not only to be able to grasp the social distribution of these practices, but principally to extract their logic. This is less about measuring the scale of a "revolution"-which all studies describe as in fact more moderate, or at least less radical, than what we might have imagined at the dawn of the twenty-first century-and more about trying to grasp what is at stake in the use, aborted use, or non-use of digital technology, through the study of specific cases. It also involves shifting our focus from the medium to its uses and users, taking into account their social position and diversity, marking a break with many works that only consider an abstract Reader independent of any context or social characteristics. In the practice of digital literature reading, how do users' representations (of digital technology, books, literature, etc.), their uses (adoption, selection, reading, comments, sharing, etc,), the cognitive processes they use while reading (perception, selection, relating, memorization, understanding, etc.), their more general practice beyond the device (readerly, cultural, and intellectual practices), and the social properties that characterize them (age, generation, qualifications, social class, professional group, gender, etc.) come into play? How in this context does digital technology differ from print?

Beyond knowledge of the evolution of reading practices, this dossier aims to contribute to a reflection on the uses and effects of the writing's mediums (McLuhan 1967; Goody 1978) and technological 
la sociologie aux sciences de l'information et de la communication avec un détour par l'histoire), à une réflexion sur les appropriations et les effets des supports de l'écrit (Mc Luhan 1967, Goody 1978) et des dispositifs technologiques (Jauréguiberry \& Proulx 2011). Comment le dispositif (c'est-à-dire le support, les fonctionnalités qu'il comporte mais aussi les discours qui l'accompagnent et le contexte dans lequel il prend place) détermine-t-il des usages ou un espace d'usages possibles ? Comment les usager 'ère-s perçoiventils/elles le dispositif et s'emparent-ils/elles ou non des possibilités offertes, voire les détournent ? Comment ces usages varient-ils socialement en fonction des contextes d'usage et des usager ère-s eux/elles-mêmes, des buts qu'ils ou elles poursuivent, de leurs compétences, de leurs schèmes de perception? Ces schèmes de perception, compétences et buts sont-ils eux-mêmes infléchis par la pratique du dispositif ? Comment distinguer les effets propres du support, de la nature des contenus, de l'organisation de ces contenus, et du contexte social (ici l'abondance de la production culturelle et de l'information disponible, l'accélération du temps, etc.) ?

\section{Des usages transposés aux pratiques} innovantes

Le dossier s'ouvre par une mise en perspective historique. En analysant les grands moments de l'histoire du livre et de la lecture, Roger Chartier a analysé la mise en place progressive d'un « ordre des livres » (Chartier 1992 ; 1996). II revient dans un entretien sur ce que fait le numérique à cet ordre des livres. S'y inscrit-il à la manière d'une forme nouvelle comme le livre de poche ou opère-til une révolution qui ouvrirait à un nouvel ordre ? De fines études de cas portant par exemple sur la Bibliothèque bleue de Troyes mais aussi sur les écrits de Shakespeare ou de Cervantès ont permis à Roger Chartier de mettre en évidence l'importance décisive du devices (Jauréguiberry \& Proulx 2011) through empirical data and analyses produced in different disciplinary frameworks (from sociology to information and communication sciences through history). How does the device (i.e. the medium, and the functions it contains, but also the discourses that accompany it and the context in which it is used) determine uses or a space of possible uses? How do users perceive the device, and do they make the most of the possibilities available, or perhaps reinvent them? How do these uses vary socially depending on the context of use and the users themselves, the aims they strive for, their skills and patterns of perception? Are these patterns of perception, skills, and aims themselves influenced by their experience of the device? How can we distinguish the effects of the medium itself from the nature and organization of its content, and social context (the abundance of cultural production and available information, time acceleration, etc.)?

\section{Uses Transposed to Innovative Practices}

This dossier begins with a historical perspective. By investigating the most important moments in the history of books and reading, Roger Chartier has analysed the gradual establishment of an "order of books" (Chartier 1992; 1996). In our interview, he re-examines the effect of digital technology on this order of books. Is it inscribed into this order as a new form, as was the case with the pocketbook, or does it operate as a revolution that would open up to a new order? Refined case studies on the Bibliothèque bleue de Troyes, for instance, but also on Shakespeare's or Cervantes' writings, allowed Roger Chartier to bring to light the critical importance of 
support et la nécessité de considérer le rôle de la matérialité des objets culturels dans la construction des significations par celles et ceux qui font usage de ces objets (voir notamment Chartier 2015).

C'est dans cette perspective que souhaite s'inscrire ce dossier en rassemblant des enquêtes circonscrites mais précises, attentives aux effets des dispositifs mais aussi à leur inscription dans un contexte social, dans lequel ils sont à la fois produits et utilisés, par

des utilisateur.rice·s eux/elles-mêmes socialement situé·e·s.

Trois enquêtes sociologiques, qui constituent la première partie de ce dossier, s'intéressent ensuite aux pratiques numériques de lecture littéraire de lecteur.rice-s dont les habitudes de lecture se sont pour l'essentiel construites à partir de l'imprimé. Gérard Mauger revient sur les principaux résultats d'une enquête qualitative menée avec Paul Gaudric et Xavier Zunigo, qui visait précisément à interroger les effets du numérique sur des individus qui sont à la fois de grand.e.s lecteur.rice.s et de fort.e.s utilisateur.rice.s du numérique, pas seulement à côté de la lecture, mais dans leur pratique de lecture elle-même (Gaudric, Mauger, Zunigo 2016). Chez ces lecteur-rice-s que le numérique n'a donc pas détourné·e·s de la lecture, quelles mutations l'enquête permet-elle d'observer ? Le numérique fait-il lire davantage (celles et ceux qui lisaient déjà beaucoup ou qui lisaient peu) ? Favorise-t-il une lecture fragmentée ? Fait-il perdre leurs repères aux lecteur.rice·s ? Plus qu'une révolution, l'enquête met au jour les continuités observables entre les pratiques de lecture numérique et imprimée et notamment

la manière dont se rejouent des différences sociales.

Stéphanie Kellner s'intéresse à un type de lectorat particulier constitué par des usager-ère-s de bibliothèques qui empruntent des liseuses proposées par leur bibliothèque et font l'expérience de ce dispositif. Cette enquête s'inscrit dans une analyse plus large du développement du numérique en bibliothèque, des injonctions the medium and the need to consider the role of the materiality of cultural objects in the construction of meaning by their users (see in particular Chartier 2015). It is from this perspective that the present dossier aims to assemble studies that are both circumscribed and specific, attentive to the effects of devices but also to their inscription in a social context in which they are both produced and used by users who are themselves socially situated.

Three sociological surveys, which constitute the first part of this dossier, examine the digital practices of literary reading by readers whose reading habits are mainly constructed from printed mediums. Gérard Mauger looks at the main results of a qualitative survey carried out with Paul Gaudric and Xavier Zunigo, which aimed to question the effects of digital media on individuals who were both avid readers and users of digital technology, not only alongside reading, but in their actual reading practice itself (Gaudric, Mauger, Zunigo 2016). Amongst these readers that digital technology did not distract from reading, what changes did the survey find? Does digital technology make people read more (for those who already read a lot or those who did not read much)? Does it lead to fragmented reading? Does it make readers lose their points of reference? More than a revolution, the survey unveils the observable continuities between digital and print reading practices and in particular the way in which social differences are re-enacted.

Stephanie Kellner is interested in a specific type of readership made up of library users who borrowed e-readers on offer by their library and experimented with the device. This study was inscribed in a wider analysis of the development of digital media in libraries, from ministerial policies to adoption by librarians and the library's 
aux appropriations par les bibliothécaires et les publics. Elle permet ici de saisir la structure sociale de ce lectorat particulier que constituent ces emprunteur.se.s de liseuses et de constater de leur part à la fois une forme de bonne volonté liée à l'intériorisation d'une image positive du numérique (mais aussi de la bibliothèque, qui la relaie) et le maintien d'un rapport traditionnel à la lecture qui finalement fait obstacle au maintien de l'usage du dispositif.

Emmanuelle Guittet confronte de même les représentations de la lecture numérique et celles associées au livre imprimé. Elle le fait à partir d'une enquête portant non pas sur le numérique mais sur la lecture de romans, forme la plus répandue de lecture littéraire aujourd'hui encore et qu'ont en ligne de mire la plupart des discours déplorant une «crise de la lecture ». Force est pour elle de constater que la lecture numérique est globalement très peu pratiquée par ces lecteur·rice·s de romans et qu'elle n'est pas véritablement envisagée comme une alternative au papier. Les entretiens menés avec ces lecteur·rice·s décrivent surtout ce qui se joue dans le rapport à la fois physique et symbolique au livre imprimé. Ils permettent ainsi de saisir en creux ce qui ferait défaut dans l'usage d'un support numérique.

Si ces trois enquêtes tendent à montrer que la lecture littéraire de genres traditionnels se transpose finalement peu ou mal au numérique (ou alors pour des raisons essentiellement pratiques et sans véritable solution de continuité avec le reste de la pratique), qu'en est-il pour des formes et formats soit rendus accessibles grâce au numérique soit nativement numériques (c'est-à-dire pensés pour les spécificités d'un support numérique et en exploitant les potentialités nouvelles) ? C'est sans doute dans ces cas où il apporte une notable plus-value (et non dans les cas où il tente de copier l'imprimé) que le numérique est susceptible de donner lieu à de réelles appropriations et surtout à des usages véritablement audience. It thus allows us to grasp the social structure of this specific readership that these e-reader users made up. It also points out a kind of goodwill on their part that is linked to the interiorization of a positive image of digital technology (but also of the library that passes it on) while maintaining a traditional relationship with reading which prevents continued use of the device.

Emmanuelle Guittet also confronts the representations of digital reading and those associated with printed books. She does so with a study not on digital reading but on novel reading, which is still the form of literature that is most commonly read nowadays, while regularly affected by the alleged "reading crisis." Guittet establishes that digital reading is generally scarcely practised by these novel readers and that it is not really considered as an alternative to paper. The interviews carried out with these readers mainly describe what is at work in the physical and symbolic relationship to printed books. They thus allow us to grasp what is allegedly missing in the use of a digital medium.

While these three studies tend to show that literary reading of traditional genres is in the end hardly or badly transposed digitally (or else for mainly practical reasons and without a real rupture with the rest of the practice), what about forms and formats that are either made accessible thanks to digital means or are originally digital (i.e. conceived for the specificities of a digital medium and thus exploiting the new potential it offers)? It is undoubtedly in these cases where it contributes notable added value (and not in the cases where it simply copies print) that digital technology might give rise to real adoptions and above all to truly new uses. As for scholarly research, digital technology has thus profoundly 
nouveaux. En matière de recherche, le numérique a ainsi modifié en profondeur la manière de travailler des chercheur.se.s, les sources qu'ils/elles peuvent mobiliser (avec un accès immédiat à des données très nombreuses et parfois inaccessibles précédemment), leur manière de s'informer, avec des variations entre les disciplines (voir Chartron, Epron, Mahé 2012) et jusqu'à leur manière d'écrire, mais sans que toutes les possibilités du numérique soient le plus souvent exploitées (Tirole \& Coutant 2014).

Philippe Chevallier, conservateur à la Bibliothèque nationale de France, propose un focus sur une base de documents numériques qui n'a quasiment pas d'équivalent en France, à savoir la base Gallica de la Bibliothèque nationale de France qui rassemble plus de cinq millions de documents imprimés numérisés. Numérisés, ces documents sont donc visuellement identiques à leur version imprimée à deux nuances près : de possibles variations de couleur et de contraste et surtout un aplatissement à deux dimensions (qui fait perdre l'épaisseur de la page et du volume). Ils sont surtout, par ce biais, accessibles à chaque instant et en tout lieu à n'importe quel-le utilisateur.rice d'un ordinateur connecté à internet. Cette numérisation massive a-t-elle eu pour effet de démocratiser l'accès à ces documents patrimoniaux ? Les textes sont-ils lus par d'autres que par les chercheur.se-s qui avaient le privilège de pouvoir les consulter dans l'antre de la Bibliothèque nationale ? Comment le sont-ils et à quelles appropriations donnent-ils lieu ? Comment les processus d'éditorialisation et d'indexation intégrés à la plateforme jouent-ils sur les pratiques de sélection et de lecture ? Si l'enquête reste à approfondir, Philippe Chevallier pose ici les jalons d'une réflexion sur ces nouveaux usages à partir de la restitution et de la comparaison des résultats de deux enquêtes menées par la Bibliothèque nationale de France elle-même sur les usager-ère-s de Gallica. II interroge notamment la manière dont les pratiques des chercheur.se's en histoire ou en études littéraires peuvent modified the way researchers work, the sources they may use (with immediate access to a large amount of previously inaccessible data), the way in which they get their information, with variations from one discipline to the next (see Chartron, Epron, Mahé 2012) and even the way they write, although all of the possibilities offered by digital technology are usually not fully harnessed (Tirole \& Coutant 2014).

Philippe Chevallier, a curator at the Bibliothèque nationale de France, focuses on a digital document database which basically has no parallel in France, namely the Gallica database which gathers more than five million digitized print documents. These digitized documents are thus visually identical to their print versions, with two small differences: possible colour and contrast variations and above all a two-dimensional flattening (thus losing the thickness of page and book). They are above all accessible at any time or place by any computer user with an internet connection. Has this mass digitization resulted in a democratization of access to archive material? Are the texts read by people other than the researchers who had the privilege of being able to consult them in the library? How are they read and what kind of adoption does this lead to? How do platform-integrated editorial and indexing processes play into selection and reading practices? Though the study could be further deepened, Philippe Chevallier sets the scene for a reflection on new uses through the restitution and comparison of the results of two studies carried out by the Bibliothèque nationale de France itself among Gallica users. He specifically questions the way in which history and literature research practices can be modified by such a digital library, but also by the way in which it is mobilized by other types of user within what Joëlle Le Marec and François Mairesse call "ordinary erudite practices" (Le Marec \& Mairesse 2017). 
être modifiées par une telle bibliothèque numérique mais aussi la manière dont celle-ci se trouve mobilisée par d'autres types d'usager-ère-s dans le cadre de ce que Joëlle Le Marec et François Mairesse nomment des " pratiques savantes ordinaires " (Le

Marec \& Mairesse 2017)

Une dernière enquête permet l'étude d'une autre pratique strictement numérique, qui combine lecture (non seulement sur support numérique, mais d'une production nativement numérique) et écriture, selon une articulation de plus en plus fréquente de deux pratiques dont on pouvait déjà observer la combinaison dans l'ordre des livres imprimés, mais qui semblent encore plus souvent réunies dans un ordre numérique qui donne une place importante aux commentaires d'expérience et au « lire pour écrire ». Les travaux de Nolwenn Tréhondart et Alexandra Saemmer ont permis d'interroger les représentations du lecteur sous-jacentes à la conception des offres de lecture numérique, représentations décisives dans la mesure où elles déterminent les fonctionnalités disponibles et donc les appropriations possibles du dispositif (Tréhondart 2014, Saemmer 2015, Saemmer \& Tréhondart 2014 ; 2017). Nolwenn Tréhondart se propose d'analyser ici la manière dont les lecteur-rice.s s'emparent réellement d'une offre de lecture littéraire créée pour le web, à savoir un feuilleton littéraire en bande dessinée numérique.

Ce dossier vise moins à couvrir l'ensemble des dispositifs et des situations de lecture numérique qu'à ouvrir le questionnement et à montrer l'intérêt d'enquêtes empiriques certes circonscrites mais précises, de manière à en susciter de nouvelles et à sortir ainsi des flots de discours qui ont accompagné les premières décennies du web en ne cessant de rejouer la querelle des anciens et des modernes.
The final paper analyses another strictly digital practice, which combines reading (not only on digital mediums, but also originally produced digital material) and writing, according to an increasingly frequent combination of two practices whose combination could already be observed in printed books, but which seem to be even more united in a digital order which emphasizes experiential commentaries and "reading to write." Nolwenn Tréhondart and Alexandra Saemmer's works question readers' representations that underlie the creation of digital reading offers. These representations are decisive in the sense that they determine available functions and thus possible adoptions of the device (Tréhondart 2014; Saemmer 2015; Saemmer \& Tréhondart 2014; 2017). Nolwenn Tréhondart analyses the way in which readers appropriate literature reading offers created for the internet, namely a literary soap opera in the form of a digital graphic novel.

This dossier does not so much aim to cover all devices and digital reading situations, but rather wishes to open up questions and point towards the benefits of empirical studies that are precise, although circumscribed. This could encourage more studies to be carried out, and thus go beyond the flow of discourse that has accompanied the first decades of the internet, in which the fight of old against new is constantly played out. 
Cécile Rabot

Université Paris Nanterre - Centre européen de sociologie et de science politique-Centre de sociologie européenne (CESSP-CSE)

\section{Références bibliographiques}

AKRICH Madeleine (1987). «Comment décrire les objets techniques ?». Techniques et culture, $9: 49-64$.

ARtIAGA Loïc (2007). Des torrents de papier. Catholicisme et lectures populaires au XIX siècle. Limoges, PULIM.

Assouline Pierre (2012). « La métamorphose du lecteur ». Le Débat, 170(3) : 78-89.

BACCINO Thierry \& DRAI-ZERBIB Véronique (2015). La Lecture numérique. $2^{\mathrm{e}}$ éd. Grenoble, PUG.

Barbagelata Pierre, InAUdi Aude, Pelissier Maud (2014). « Le numérique vecteur d'un renouveau des pratiques de lecture : leurre ou opportunité ? ». Études de communication. Langages, information, médiations, 43 : 17-38.

Barbe Lionel, Merzeau Louise, Schafer Valérie (2015). Wikipédia, objet scientifique non identifié. Nanterre, Presses universitaires de Paris Ouest. BAYARD Pierre (2006). Comment parler des livres que l'on n'a pas lus ? Paris, Minuit.

BÉLISLE Claire (dir.) (2011). Lire dans un monde numérique. Villeurbanne, Presses de l'Enssib.

BONNÉRY Stéphane (dir.) (2015). Supports pédagogiques et inégalités scolaires : études sociologiques. Paris, La Dispute.

BOULLIER Dominique (2011). “"Profils, alerte et vidéo” : de l'outre-lecture à la fin de la lecture ? ». In Evans Christophe (dir.). Lectures et lecteurs a l'heure d'Internet. Livre, presse, bibliothèques. Paris, Cercle de la librairie, 41-58.

Boullier Dominique \& CRÉPEL Maxime (2013). Pratiques de lecture et d'achat de livres numériques. Étude réalisée pour le MOTif. [Consulté le 25 juin 2020.]
Cécile Rabot

Université Paris Nanterre - Centre européen de sociologie et de science politique-Centre de sociologie européenne (CESSP-CSE)

\section{References}

AKRICH Madeleine (1987). "Comment décrire les objets techniques?." Techniques et culture, 9: 49-64.

Artiaga Loïc (2007). Des torrents de papier. Catholicisme et lectures populaires au XIX siècle. Limoges, PULIM.

Assouline Pierre (2012). "La métamorphose du lecteur." Le Débat, 170(3): 78-89.

BACCINO Thierry \& DRAI-ZERBIB Véronique (2015). La Lecture numérique. $2^{\mathrm{e}}$ éd. Grenoble, PUG.

Barbagelata Pierre, Inaudi Aude, Pelissier Maud (2014). "Le numérique vecteur d'un renouveau des pratiques de lecture: leurre ou opportunité?." Études de communication. Langages, information, médiations, 43: 17-38.

Barbe Lionel, Merzeau Louise, Schafer Valérie (2015). Wikipédia, objet scientifique non identifié. Nanterre, Presses universitaires de Paris Ouest.

BAYARD Pierre (2006). Comment parler des livres que l'on n'a pas lus?. Paris, Minuit.

BÉLISLE Claire (ed.) (2011). Lire dans un monde numérique. Villeurbanne, Presses de l'Enssib.

BONNÉRY Stéphane (ed.) (2015). Supports pédagogiques et inégalités scolaires: études sociologiques. Paris, La Dispute.

BOULLIER Dominique (2011). “'Profils, alerte et vidéo': de l'outre-lecture à la fin de la lecture?." In Evans Christophe (ed.). Lectures et lecteurs à l'heure d'Internet. Livre, presse, bibliothèques. Paris, Cercle de la librairie, 41-58.

BOUlLIER Dominique \& CRÉPEL Maxime (2013). Pratiques de lecture et d'achat de livres numériques. Étude réalisée pour le MOTif. [Accessed on 25 June 2020. 
Boullier Dominique, Ghitalla Franck, Le Douarin Laurence, Neau Aurélie, Gkouskou-Giannakou Pergia (2003). L'Outre-lecture. Manipuler, (s') approprier, interpréter le web. Paris, Bibliothèque publique d'information.

BOUVERESSE Jacques (2008). La Connaissance de l'écrivain. Sur la littérature, la vérité \& la vie. Marseille, Agone.

CARRIÈre Jean-Claude \& Eco Umberto (2009). N'espérez pas vous débarrasser des livres. Entretiens menés par Jean-Philippe de Tonnac. Paris, Grasset.

CASATI Roberto (2013). Contre le colonialisme numérique : manifeste pour continuer à lire. Traduit de l'italien par Pauline Colonna d'Istria. Paris, Albin Michel.

CHARTIER Roger (1992). L'Ordre des livres. Lecteurs, auteurs, bibliothèques en Europe entre XIV et XVIII siècle. Aix-en-Provence, Alinea.

CHARTIER Roger (1996). Culture écrite et société. L'ordre des livres. Paris, Albin Michel.

CHARTIER Roger (2015). La Main de l'auteur et l'esprit de l'imprimeur. XVI XVIII siècle. Paris, Gallimard.

Chartron Ghislaine, ÉPron Benoît, Mahé Annaïg (dir.) (2012). Pratiques documentaires numériques à l'université. Villeurbanne, Presses de l'Enssib.

COHEN Laurent (2009). Pourquoi les chimpanzés ne parlent pas et 30 autres questions sur le cerveau de l'homme. Paris, Odile Jacob.

Compagnon Antoine (2012). « Lire numérique ». Le Débat, 170(3) : 103106.

CoUlANGEON Philippe \& LeMEL Yannick (2009). « Les pratiques culturelles et sportives des Français : arbitrage, diversité et cumul ». Économie et Statistique 423(1) : 3-30.

Crouzet Thierry (2015). La Mécanique du texte : essai. Toulouse, Publie. net.
Boullier Dominique, GHITALla Franck, Le DouARIn Laurence, NeAu Aurélie, Gkouskou-Giannakou Pergia (2003). L'Outre-lecture. Manipuler, (s') approprier, interpréter le web. Paris, Bibliothèque publique d'information.

Bouveresse Jacques (2008). La Connaissance de l'écrivain. Sur la littérature, la vérité \& la vie. Marseille, Agone.

CARrière Jean-Claude \& Eco Umberto (2009). N'espérez pas vous débarrasser des livres. Interviews conducted by Jean-Philippe de Tonnac. Paris, Grasset.

CASATI Roberto (2013). Contre le colonialisme numérique: manifeste pour continuer à lire. Translated from Italian by Pauline Colonna d'Istria. Paris, Albin Michel.

CHARTIER Roger (1994) [1992]. The Order of Books. Readers, Authors, and Libraries in Europe Between the Fourteenth and Eighteenth Centuries. Translated by Lydia G. Cochrane. Palo Alto, Stanford University Press

CHARTIER Roger (1996). Culture écrite et société. L'ordre des livres. Paris, Albin Michel.

CHARTIER Roger, The Author's Hand and the Printer's Mind: Transformations of the Written Word in Early Modern Europe. Translated by Lydia G. Cochrane. Cambridge, Polity Press 2013.

Chartron Ghislaine, Épron Benoît, MahÉ Annaïg (eds.) (2012). Pratiques documentaires numériques à l'université. Villeurbanne, Presses de l'Enssib.

COHEN Laurent (2009). Pourquoi les chimpanzés ne parlent pas et 30 autres questions sur le cerveau de l'homme. Paris, Odile Jacob.

Compagnon Antoine (2012). "Lire numérique." Le Débat, 170(3): 103-106.

CoulANGeON Philippe \& LEMEL Yannick (2009). "Les pratiques culturelles et sportives des Français: arbitrage, diversité et cumul." Économie et Statistique, 423(1): 3-30.

Crouzet Thierry (2015). La Mécanique du texte: essai. Toulouse, Publie. net. 
DARnton Robert (2011). Apologie du livre. Demain, aujourd'hui, hier. Traduit de l'anglais par Jean-François Sené. Paris, Gallimard (Folio).

Dehaene Stanislas (2007). Les Neurones de la lecture. Paris, Odile Jacob.

DuRAnd Pascal \& Servals Christine (dir.) (2017). L'Intervention du support. Médiation esthétique et énonciation éditoriale. Liège, Presses Universitaires de Liège.

Evans Christophe (dir.) (2011). Lectures et lecteurs à l'heure d'Internet. Livre, presse, bibliothèques. Paris, Cercle de la librairie.

GaUdric Paul, MaUger Gérard, ZUNigo Xavier (2016). Lectures numériques. Une enquête sur les grands lecteurs. Paris, Bibliothèque publique d'information. [Consulté le 25 juin 2020.]

GenetTe Gérard (1987). Seuils. Paris, Seuil.

Goody Jack (1978) [1977]. La Raison graphique : la domestication de la pensée sauvage. Traduit de l'anglais et présenté par Jean Bazin et Alban Bensa. Paris, Minuit.

Granjon Fabien \& Combes Clément (2007). "La numérimorphose des pratiques de consommation musicale. Le cas des jeunes amateurs ». Réseaux, 145-146 : 291-334.

Grignon Claude \& PASSERon Jean-Claude (1989). Le Savant et le Populaire. Misérabilisme et populisme en sociologie et en littérature. Paris, Éditions du Seuil.

Guillaud Hubert (2010). « Le papier contre l'électronique ». In Dacos Marin (dir.). Read/Write Book. Le livre inscriptible. Marseille, OpenEdition Press : 29-48. [Consulté le 25 juin 2020.]

GUILLORY John (2010). «Close reading : Prologue and Epilogue ». ADE Bulletin, 149.

GUITTET Emmanuelle (2018). Lecteurs et lectrices de romans face à la prescription littéraire : une enquête sociologique sur les choix de lecture à l'ère numérique. Thèse de doctorat en sociologie. Paris, Université Paris Sorbonne Nouvelle, 2018.
DaRnton Robert (2010). The Case for Books: Past, Present, and Future. New York, Public affairs.

Dehaene Stanislas (2007). Les Neurones de la lecture. Paris, Odile Jacob. Durand Pascal \& Servals Christine (eds.) (2017). L'Intervention du support. Médiation esthétique et énonciation éditoriale. Liège, Presses Universitaires de Liège.

Evans Christophe (ed.) (2011). Lectures et lecteurs à l'heure d'Internet. Livre, presse, bibliothèques. Paris, Cercle de la librairie.

GaUdRIC Paul, MaUger Gérard, Zunigo Xavier (2016). Lectures numériques. Une enquête sur les grands lecteurs. Paris, Bibliothèque publique d'information. [Accessed on 25 June 2020.]

GenETTE Gérard (1997). Paratexts: Thresholds of Interpretation. Translated by Jane E. Lewin. Cambridge, Cambridge University Press.

Goody Jack (1977). The Domestication of the Savage Mind. Cambridge/ London/New York, Cambridge University Press.

Granjon Fabien \& Combes Clément (2007). "La numérimorphose des pratiques de consommation musicale. Le cas des jeunes amateurs." Réseaux, 145-146: 291-334.

Grignon Claude \& Passeron Jean-Claude (1989). Le Savant et le Populaire. Misérabilisme et populisme en sociologie et en littérature. Paris, Éditions du Seuil.

GUILLAUD Hubert (2010). "Le papier contre l'électronique." In Dacos Marin (ed.). Read/Write Book. Le livre inscriptible. Marseille, OpenEdition Press: 29-48. [Accessed on 25 June 2020.]

GUILLORY John (2010). "Close Reading: Prologue and Epilogue." $A D E$ Bulletin, 149 .

GUITTET Emmanuelle (2018). Lecteurs et lectrices de romans face à la prescription littéraire: une enquête sociologique sur les choix de lecture à l'ère numérique. $\mathrm{PhD}$ dissertation, Sociology. Paris, Université Paris Sorbonne Nouvelle, 2018 
HAYLES N. Katherine (2016). Lire et penser en milieux numériques. Attention, récits, technogenèse. Grenoble, ELLUG.

JaURÉGuiberRY Francis \& Proulx Serge (2011). Usages et enjeux des technologies de communication. Toulouse, Érès.

JOUET Josiane \& RIEFFEL Rémy (dir.) (2013). S'informer à l'ère numérique. Rennes, Presses universitaires de Rennes.

LABBÉ Stéphane (2016). « Le livre numérique au Québec : le cas des emprunts aux bibliothèques publiques autonomes ». Mémoires du livre/ Studies in Book Culture, 8(1). [Consulté le 25 juin 2020.]

LAUGIER Sandra (dir.) (2006). Éthique, littérature, vie humaine. Paris, PUF. LEGENDRE Bertrand (2019). Ce que le numérique fait aux livres. Grenoble, Presses universitaires de Grenoble.

Le MAREC Joëlle \& MaIRESSE François (2017). Enquête sur les pratiques savantes ordinaires : collectionnisme numérique et environnements matériels. Lormont, le Bord de l'eau.

LEVERATTO Jean-Marc \& LEONTSINI Mary (2008). Internet et la sociabilité littéraire. Paris, Bibliothèque publique d'information.

LYON-CAEN Judith (2006). La Lecture et la vie : les usages du roman au temps de Balzac. Paris, Tallandier.

Mangen Anne, Walgermo Bente, Brønnick Kolbjorn (2013). « Reading linear texts on paper versus computer screen. Effects on reading comprehension ». International Journal of Educational Research, 58(1), 61-68

MAuger Gérard \& PoliaK Claude (1998). « Les usages sociaux de la lecture ». Actes de la recherche en sciences sociales, 123 : 3-24.

Mauger Gérard, Poliak Claude, Pudal Bernard (1999). Histoires de lecteurs. Paris, Nathan

McLUHAN Marshall (1967) [1962]. La Galaxie Gutenberg ["the Gutenberg galaxy"], face à l'ère électronique, les civilisations de l'âge oral a l'imprimerie. Traduit de l'anglais par Jean Paré. Paris, Mame, 1967.
HAYLES N. Katherine (2016). Lire et penser en milieux numériques. Attention, récits, technogenèse. Grenoble, ELLUG.

JaurÉGuiberry Francis \& Proulx Serge (2011). Usages et enjeux des technologies de communication. Toulouse, Érès.

Jouet Josiane \& RiefFel Rémy (eds.) (2013). S'informer à l'ère numérique. Rennes, Presses universitaires de Rennes.

LABBÉ Stéphane (2016). "Le livre numérique au Québec: le cas des emprunts aux bibliothèques publiques autonomes." Mémoires du livre/ Studies in Book Culture, 8(1). [Accessed on 25 June 2020.]

LAUGIER Sandra (ed.) (2006). Éthique, littérature, vie humaine. Paris, PUF.

LEGENDRE Bertrand (2019). Ce que le numérique fait aux livres. Grenoble, Presses universitaires de Grenoble.

LE MAREC Joëlle \& MAIRESSE François (2017). Enquête sur les pratiques savantes ordinaires: collectionnisme numérique et environnements matériels. Lormont, Le Bord de l'eau.

LEVERATTO Jean-Marc \& LEONTSINI Mary (2008). Internet et la sociabilité littéraire. Paris, Bibliothèque publique d'information.

LYON-CAEN Judith (2006). La Lecture et la vie: les usages du roman au temps de Balzac. Paris, Tallandier.

Mangen Anne, Walgermo Bente, Brønnick Kolbjorn (2013). "Reading linear texts on paper versus computer screen. Effects on reading comprehension." International Journal of Educational Research, 58(1), 61-68.

MaUger Gérard \& Poliak Claude (1998). "Les usages sociaux de la lecture." Actes de la recherche en sciences sociales, 123: 3-24.

Mauger Gérard, Poliak Claude, Pudal Bernard (1999). Histoires de lecteurs. Paris, Nathan.

McLUHAN Marshall (1962). The Gutenberg Galaxy: The Making of Typographic Man. London, Routledge and Kegan Paul. 
Melot Michel (2006). Livre,. Photographies de Nicolas TAfFIN. Paris, L'CEil neuf.

Mercklé Pierre \& Octobre Sylvie (2012). « La stratification sociale des pratiques numériques des adolescents ». RESET, 1. [Consulté le 25 juin 2020].

Miall David S. \& Dobson Teresa (2001). « Reading hypertext and the experience of literature ", Journal of digital information, 2(1). [Consulté le 25 juin 2020.]

MIGUET Mathilde (2014). «Livres numériques : stratégies des lecteurs dans leurs pratiques. " Études de communication. Langages, information, médiations, $43:$ 57-74.

MoATtI Alexandre (2012). « Le numérique, adjectif substantivé. » Le Débat, 170(3) : 133-37.

MusIL Robert (2004). L'Homme sans qualités : roman [Der Mann ohne Eigenschaften]. Traduit par Philippe Jaccottet. Nouv. éd. T. 1. Paris, Seuil.

Nussbaum Martha Craven (1990). Love's Knowledge. Essays on Philosophy and Literature. New York, Oxford, Oxford University Press.

Paquienséguy Françoise \& Miguet Mathilde (2015). Le Lectorat numérique. Usages et pratiques d'écrans : résultats d'enquête 20122013. Paris, Éditions des Archives Contemporaines.

Paveau Marie-Anne (2015). " Ce qui s'écrit dans les univers numériques. Matières technolangagières et formes technodiscursives ". Itinéraires. Littérature, textes, cultures, 2014(1). [Consulté le 25 juin 2020.]

Petitjean Anne-Marie \& Houdart-Merot Violaine (2015). Numérique et écriture littéraire. Mutations des pratiques. Paris, Hermann.

PetRucci Armando (1990). « Lire pour lire. La lecture littéraire ». Textuels, 7. Repris in Cavallo Guglielmo \& ChaRTIER Roger (dir.) (2001). Histoire de la lecture dans le monde occidental, Paris, Seuil, 431-457.
Melot Michel (2006). Livre,. Photographies de Nicolas TAffin. Paris, L'CEil neuf.

MerCKLÉ Pierre \& Octobre Sylvie (2012). "La stratification sociale des pratiques numériques des adolescents." RESET, 1. [Accessed on 25 June 2020.

MiALl David S. \& Dobson Teresa (2001). "Reading Hypertext and the Experience of Literature". Journal of digital information, 2(1). [Accessed on 25 June 2020.]

MigUET Mathilde (2014). "Livres numériques: stratégies des lecteurs dans leurs pratiques." Études de communication. Langages, information, médiations, 43: 57-74.

MoATTI Alexandre (2012). "Le numérique, adjectif substantivé." Le Débat, 170(3): 133-37.

MusIL Robert (1979). The Man Without Qualities [Der Mann ohne Eigenschaften]. Translated from German by Ernst Kaiser and Eithne Wilkins. London: Pan Books, Secker \& Warburg.

Nussbaum Martha Craven (1990). Love's Knowledge. Essays on Philosophy and Literature. New York, Oxford, Oxford University Press.

PAquienséguY Françoise \& Miguet Mathilde (2015). Le Lectorat numérique. Usages et pratiques d'écrans: résultats d'enquête 20122013. Paris, Éditions des Archives Contemporaines.

Paveau Marie-Anne (2015). "Ce qui s'écrit dans les univers numériques. Matières technolangagières et formes technodiscursives." Itinéraires. Littérature, textes, cultures, 2014(1). [Accessed on 25 June 2020.]

Petituean Anne-Marie \& Houdart-Merot Violaine (2015). Numérique et écriture littéraire. Mutations des pratiques. Paris, Hermann.

PetRucci Armando (1990). "Lire pour lire. La lecture littéraire." Textuels, 7. Repris in Cavallo Guglielmo \& Chartier Roger (eds.) (2001). Histoire de la lecture dans le monde occidental. Paris, Seuil, 431-457. 
PIROLLI Fabrice (dir.) (2015). Le Livre numérique au présent. Pratiques de lecture, de prescription et de médiations. Dijon, Éditions Universitaires de Dijon.

RENARD Fanny (2011). Les Lycéens et la lecture : entre habitudes et sollicitations. Rennes, Presses Universitaires de Rennes.

Renard Hervé (1995). " Achat et emprunt de livres : concurrence ou complémentarité. » Bulletin des Bibliothèques de France, 40(5) : 26-34.

RiEFFEL Rémy (2014). Révolution numérique, révolution culturelle? Paris, Gallimard.

ROUET François (1995). « De la concurrence entre les pratiques d'emprunt et d'achat de livres. L'impossible simplicité ». In SEIBEL Bernadette (dir.). Lire, Faire lire : des usages de l'écrit aux politiques de lecture. Paris, Le Monde-Éditions, 189-224.

SaEMmer Alexandra (2015). Rhétorique du texte numérique. Figures de la Lecture, anticipations de pratiques. Villeurbanne, Presses de l'Enssib.

SAEMmer Alexandra \& TréHONDART Nolwenn (2014). « Les figures du livre numérique "augmenté" au prisme d'une rhétorique de la réception ". Études de communication. Langages, information, médiations, 43 : 10728.

Saemmer Alexandra \& TréHondart Nolwenn (2017). Livres d'art numériques : de la conception à la réception. Paris, Hermann.

Souchier Emmanuel (1996). "L'image du texte. Pour une théorie de l'énonciation éditoriale ». Cahiers de Médiologie, 6 : 137-145.

SPITZER Manfred (2019). Les Ravages des écrans. Les pathologies à l'ère du numérique. Traduit de l'allemand par Frédéric Joly. Paris, L'Échappée.

STEINER George (2003). "Les livres ont besoin de nous ». In Les Logocrates. Traduit de l'anglais par Pierre-Emmanuel Dauzat. Paris, L'Herne : 65 sqq.

TIROLE Delphine \& CoutANT Alexandre (2014). " L'usage des terminaux numériques dans les pratiques de lecture savante des enseignants-
PIROLLI Fabrice (ed.) (2015). Le Livre numérique au présent. Pratiques de lecture, de prescription et de médiations. Dijon, Éditions Universitaires de Dijon.

RenaRD Fanny (2011). Les Lycéens et la lecture: entre habitudes et sollicitations. Rennes, Presses Universitaires de Rennes.

RenARD Hervé (1995). "Achat et emprunt de livres: concurrence ou complémentarité." Bulletin des Bibliothèques de France, 40(5): 26-34.

RiEFFEL Rémy (2014). Révolution numérique, révolution culturelle?. Paris, Gallimard.

ROUET François (1995). "De la concurrence entre les pratiques d'emprunt et d'achat de livres. L'impossible simplicité." In SEIBEL Bernadette (ed.). Lire, Faire lire: Des usages de l'écrit aux politiques de lecture. Paris, Le Monde-Éditions, 189-224.

SaEMmer Alexandra (2015). Rhétorique du texte numérique. Figures de la Lecture, anticipations de pratiques. Villeurbanne, Presses de l'Enssib.

SAEMmer Alexandra \& TrÉHONDART Nolwenn (2014). "Les figures du livre numérique 'augmenté' au prisme d'une rhétorique de la réception." Études de communication. Langages, information, médiations, 43: 107-28.

SAEMmer Alexandra \& TréHondart Nolwenn (2017). Livres d'art numériques: de la conception à la réception. Paris, Hermann.

Souchier Emmanuel (1996). "L'image du texte. Pour une théorie de l'énonciation éditoriale." Cahiers de Médiologie, 6: 137-145.

SpITZER Manfred (2019). Les Ravages des écrans. Les pathologies à l'ère du numérique. Translated from German by Frédéric Joly. Paris, L'Échappée.

StEINER George (2003). "Les livres ont besoin de nous." In Les Logocrates. Translated from English by Pierre-Emmanuel Dauzat. Paris, L'Herne: 65 sqq.

TIROLE Delphine \& CoutANT Alexandre (2014). "L'usage des terminaux numériques dans les pratiques de lecture savante des enseignants- 
chercheurs. Entre ancrage socioculturel et évolution du dispositif sociotechnique ». Études de communication. Langages, information, médiations, $43:$ 39-56.

TRÉHONDART Nolwenn (2014). « Le livre numérique "augmenté" au regard du livre imprimé : positions d'acteurs et modélisations de pratiques ». Les Enjeux de l'information et de la communication, 15(2) : 23-37.

VANDENDORPE Christian (1999). Du papyrus à l'hypertexte. Essais sur les mutations du texte et de la lecture. Paris, La Découverte.

Vincent GÉRARD Armelle \& VAYSSETtes Benoit (2018). Les Jeunes Adultes et la lecture. Paris, Centre national du livre, IPSOS. [Consulté le 25 juin 2020.]

WIART Louis (2017). La Prescription littéraire en réseaux. Enquête dans l'univers numérique. Villeurbanne, Presses de l'Enssib.

Wolf Maryanne (2007). Proust and the Squid. The Story and Science of the Reading Brain. New York, Harper.

ZHU Erping (1999). « Hypermedia Interface Design : The Effects of Number of Links and Granularity of Nodes ». Journal of Educational Multimedia and Hypermedia, 8(3) : 331-358. chercheurs. Entre ancrage socioculturel et évolution du dispositif sociotechnique." Études de communication. Langages, information, médiations, 43: 39-56.

TRÉHONDART Nolwenn (2014). "Le livre numérique 'augmenté' au regard du livre imprimé: positions d'acteurs et modélisations de pratiques." Les Enjeux de l'information et de la communication, 15(2): 23-37.

VANDENDORPE Christian (1999). Du papyrus à l'hypertexte. Essais sur les mutations du texte et de la lecture. Paris, La Découverte.

Vincent GÉRARd Armelle \& Vayssettes Benoit (2018). Les Jeunes Adultes et la lecture. Paris, Centre national du livre, IPSOS. [Accessed on 25 June 2020.]

WIART Louis (2017). La Prescription littéraire en réseaux. Enquête dans l'univers numérique. Villeurbanne, Presses de l'Enssib.

Wolf Maryanne (2007). Proust and the Squid. The Story and Science of the Reading Brain. New York, Harper.

ZHU Erping (1999). "Hypermedia Interface Design: The Effects of Number of Links and Granularity of Nodes." Journal of Educational Multimedia and Hypermedia, 8(3): 331-358. 